\section{Article}

Cite this article: Holt T, Glasser NF (2022). Changes in area, flow speed and structure of southwest Antarctic Peninsula ice shelves in the 21st century. Journal of Glaciology $\mathbf{6 8}(271)$, 927-945. https://doi.org/10.1017/jog.2022.7

Received: 24 August 2021

Revised: 11 January 2022

Accepted: 21 January 2022

First published online: 23 February 2022

\section{Key words:}

Antarctic glaciology; ice shelves; ice velocity; remote sensing; structural glaciology

Author for correspondence:

Tom Holt,

E-mail: toh08@aber.ac.uk

\title{
Changes in area, flow speed and structure of southwest Antarctic Peninsula ice shelves in the 21st century
}

\section{Tom Holt (D) and Neil F Glasser (D)}

Centre for Glaciology, Department of Geography and Earth Sciences, Aberystwyth University, Aberystwyth, Wales SY23 3DB, UK

\begin{abstract}
Since the mid-20th century, ice shelves around the Antarctic Peninsula have declined in extent and thickness, and some have shown signs of structural instability. Here, using satellite imagery from 1999/2000 to 2019/20 (Landsat 7 and 8, Sentinel-2 and ASTER), we measure areal changes, calculate surface flow speeds, and quantify structural changes of Bach, Stange and George VI ice shelves, located in the southwest Antarctic Peninsula. We recorded a total area loss of $797.5 \mathrm{~km}^{2}$ from $2009 / 10$ to $2019 / 20$, though spatial and temporal patterns varied at individual ice fronts. Flow speeds remained largely stable over the observation periods, but notable acceleration was calculated for Bach Ice Shelf, and at the northern and southern extents of George VI Ice Shelf. Open fractures widened and lengthened between 2009/10 and 2019/20 on all three ice shelves. We conclude that Stange Ice Shelf is stable, and not under any immediate threat of enhanced recession. Continued ice-mass loss and consequential speed up of George VI South may cause further fracturing and destabilisation in the coming decades. Of more immediate concern are the glaciological changes noted for Bach Ice Shelf and George VI North; substantial areas of stabilising ice have already, or will soon be removed, that may lead to enhanced recession within the next decade.
\end{abstract}

\section{Introduction}

Atmospheric warming and changes to oceanic conditions over the latter half of the 20th century and beginning of the 21st century have resulted in accelerated recession and mass loss from glaciers and ice shelves around the Antarctic Peninsula (Cook and others, 2016; Hogg and others, 2017; Fieber and others, 2018). Changes include the rapid disintegration of several ice shelves, including Larsen A (Rott and others, 1996), Prince Gustav (Cooper and others, 1997) and Larsen B (Rack and Rott, 2004), and the enhanced recession of Wilkins (Braun and others, 2009) and Larsen C (Hogg and Gudmundsson, 2017). The timing of ice-shelf disintegration events coincides with the northern migration of the $-9^{\circ} \mathrm{C}$ mean annual isotherm (Morris and Vaughan, 2003), a lengthening of the melt season (Barrand and others, 2013) and where positive degree days exceed $200 \mathrm{~d} \mathrm{a}^{-1}$ (Fyke and others, 2010). Furthermore, recent research (e.g. Pritchard and others, 2012; Paolo and others, 2015; Adusumilli and others, 2018) has illustrated the significance of basal melting on ice-shelf mass balance, related to changes in oceanic conditions (e.g. Robertson and others, 2002; Meredith and King, 2005; Padman and others, 2012) and sea-ice concentrations (Stammerjohn and others, 2008; Massom and others, 2018).

As well as atmospheric and ocean-driven thinning, further conditioning factors that enhance ice-front recession include: (i) a concave ice-front geometry from an ice shelf s lateral pinning points (e.g. Doake and others, 1998); (ii) an increase in flow speed in years preceding disintegration (e.g. Rack and others, 2000; Rack and Rott, 2004); (iii) the presence of pinning points such as ice rises (e.g. Hughes, 1983; Braun and others, 2009); (iv) structural (in)stability along suture zones (e.g. Glasser and Scambos, 2008; Kulessa and others, 2014) and at the calving front (e.g. Braun and others, 2009; Holt and others, 2013); and (v) the presence of either surface meltwater (e.g. Scambos and others, 2003) or infiltrated brine within the ice shelf (Scambos and others, 2009). A combination of these conditioning factors can lead to major calving events through hydrofracture (Scambos and others, 2000, 2003; MacAyeal and others, 2003; Banwell and others, 2013, 2019) or plate-bending initiated by differential stresses at the ice front (Scambos and others, 2009). Regardless of the final processes involved, the removal of buttressing ice has been shown to alter the dynamics of grounded ice, increasing tributary glacier flow speed, and resulting in greater discharge of fresh, meteoric ice into the Southern Ocean (Rott and others, 2002, 2007, 2018; Hulbe and others, 2008; Berthier and others, 2012; Fürst and others, 2016; Friedl and others, 2018).

Mercer (1978) and Vieli and others (2007) noted that glaciological changes (e.g. ice-front morphology and evolution, glacier structures and ice-shelf dynamics) occur well in advance of enhanced recession and breakup of ice shelves. This led Glasser and Scambos (2008), Glasser and others $(2009,2011)$, Braun and others $(2009)$ and Holt and others $(2013,2014)$ to examine an extensive back-catalogue of satellite imagery to investigate the glaciological conditions of Antarctic Peninsula ice shelves. Their work collectively illustrated the requirement for 


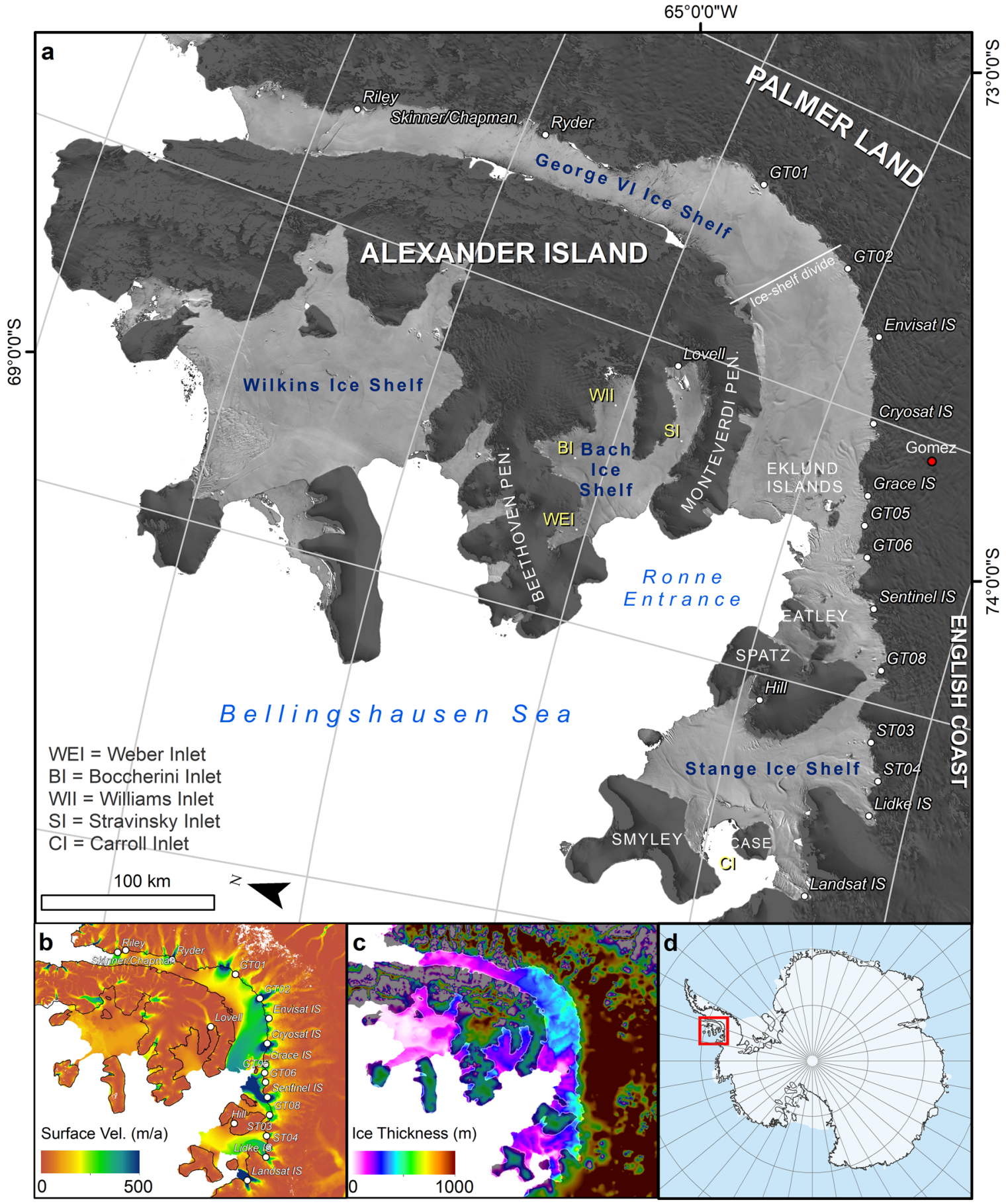

Fig. 1. (a) Location of Bach, Stange and George VI ice shelves on the Antarctic Peninsula. Red dot between Cryosat Ice Stream (IS) and Grace IS is the location of the Gomez ice core as mentioned in the text. The location of the ice divide on George VI Ice Shelf illustrates the divergence of flow towards the northern and southern region. GT, George VI Tributary; ST, Stange Tributary. (b) MEaSUREs surface velocity (Rignot and others, 2011). (c) BedmapV2 ice thickness (Fretwell and others, 2013). (d) Extent of panels (a-c) in the wider context of Antarctica.

monitoring glaciological factors to identify precursors to ice-shelf disintegration and assess the impacts of environmental change on ice-shelf systems.

The aim of this study is to investigate recent glaciological changes to three ice shelves on the southwest Antarctic Peninsula: Bach, Stange and George VI (Fig. 1). Changes to George VI and Stange ice shelves were described by Holt and others (2013) and Holt and others (2014) respectively, but now a further decade's worth of satellite imagery has been acquired, offering higher quality and finer-resolution data to assess more recent developments. A combination of Landsat 7 ETM+, Landsat 8 OLI and Sentinel 2 satellite scenes, supported by
ASTER imagery, is used to measure decadal areal changes at the ice fronts, examine structural and surface feature evolution, and calculate ice-shelf flow speed from 2009/10 to 2019/20.

\section{Southwest Antarctic Peninsula ice shelves}

Atmospheric temperature reconstructions from the Gomez $\delta^{18} \mathrm{O}$ ice core record (Thomas and other, 2008) (location in Fig. 1a) show a warming trend in the southwest Antarctic Peninsula since the $1900 \mathrm{~s}$, and by $\sim 2.7^{\circ} \mathrm{C}$ since the 1950 s (Thomas and others, 2009) despite short-lived periods of atmospheric cooling on the peninsula in the mid-to-late 1990s and 2015/16 (Picard 
Table 1. Key attributes of George VI Ice Shelf, Stange Ice Shelf and Bach Ice Shelf

\begin{tabular}{|c|c|c|c|c|}
\hline Attribute & $\begin{array}{l}\text { Bach Ice } \\
\text { Shelf }\end{array}$ & $\begin{array}{l}\text { Stange } \\
\text { Ice Shelf }\end{array}$ & $\begin{array}{l}\text { George VI } \\
\text { Ice Shelf }\end{array}$ & Sources/comments \\
\hline Area $\left(\mathrm{km}^{2}\right)$ in 2010 (GVI/Bach) and 2011 (Stange) & 4536 & 7917 & 23370 & Holt (2012) \\
\hline Centre latitude $\left({ }^{\circ}\right)$ & -72.04 & -73.22 & -72.35 & \\
\hline Centre longitude $\left({ }^{\circ}\right)$ & -72.10 & -76.67 & -69.62 & \\
\hline Grounding line flux $\left(\mathrm{Gt} \mathrm{a}^{-1}\right)$ (ca. 2008) & $5.4 \pm 1$ & $21.0 \pm 3$ & $68.2 \pm 5$ & Rignot and others (2013) \\
\hline Ice-front flux (Gt a $\left.{ }^{-1}\right)$ (ca. 2008) & $0.8 \pm 0.2$ & $4.6 \pm 0.8$ & $5.7 \pm 1.2$ & Rignot and others (2013) \\
\hline Mean firn thickness (m) & 14.6 & 15.8 & 12.9 & $\begin{array}{l}\text { Firn correction depth from van den } \\
\text { Broeke and others (2008) via ALBMAP dataset } \\
\text { (see Le Brocq and others, 2010) }\end{array}$ \\
\hline Ice-shelf surface mass balance (SMB) $\left(\mathrm{Gt} \mathrm{a}^{-1}\right)$ (ca. 2008) & $1.8 \pm 0.3$ & $6.0 \pm 1$ & $12.7 \pm 2$ & Rignot and others (2013) \\
\hline Ice-shelf basin SMB $\left(\mathrm{Gt}^{-1}\right)(1979-2017)$ & No data & $16.5 \pm 1.0$ & $70.3 \pm 4.0$ & Rignot and others (2019) \\
\hline Surface height change rate $\left(\mathrm{m} \mathrm{a}^{-1}\right)(1992-2016)$ & $-0.07 \pm 0.02$ & $-0.05 \pm 0.02$ & $-0.08 \pm 0.01$ & Adusumilli and others (2018) \\
\hline Thickening $\left(\mathrm{Gt} \mathrm{a}^{-1}\right)$ (ca. 2008) & $4.0 \pm 0.3$ & $-5.6 \pm 5$ & $-13.8 \pm 16$ & Rignot and others (2013) \\
\hline Thickening $\left(\mathrm{m} \mathrm{a}^{-1}\right)$ (ca. 2008) & $-0.87 \pm 0.1$ & $-0.69 \pm 0.6$ & $-0.59 \pm 0.7$ & Rignot and others (2013) \\
\hline Basal loss $\left(\mathrm{Gt} \mathrm{a}^{-1}\right)$ (ca. 2008) & $10.4 \pm 1$ & $28.0 \pm 6$ & $89.0 \pm 17$ & Rignot and others (2013) \\
\hline Basal melt rate $\left(\mathrm{m} \mathrm{a}^{-1}\right)$ (ca. 2008) & $2.28 \pm 0.3$ & $3.49 \pm 0.7$ & $3.80 \pm 0.7$ & Rignot and others (2013) \\
\hline Basal melt rate $\left(\mathrm{m} \mathrm{a}^{-1}\right)(1994-2016)$ & $1.7 \pm 2.6$ & $3.2 \pm 1.5$ & $3.2 \pm 1.9$ & Adusumilli and others (2018) \\
\hline Net mass balance $\left(\mathrm{m} \mathrm{a}^{-1}\right)(1994-2016)$ & $-1.0 \pm 3.0$ & $-1.1 \pm 1.5$ & $-1.2 \pm 1.8$ & Adusumilli and others (2018) \\
\hline $\begin{array}{l}\text { Passive shelf ice \% (ca. 2008) (i.e. the portion of ice } \\
\text { shelf that can be removed without major } \\
\text { implications for its dynamics) }\end{array}$ & 3.2 & 8.8 & 4.3 & Fürst and others (2016) \\
\hline
\end{tabular}

Sources noted in final column.

and others, 2007; Turner and others, 2016; Banwell and others, 2021). In 2003 , the seemingly critical $-9^{\circ} \mathrm{C}$ mean annual isotherm stretched across Alexander Island into George VI Sound, before heading north towards Larsen C (Morris and Vaughan, 2003). Simultaneously, the upper ocean on the western Antarctic Peninsula underwent warming in the second half of the 20th century (Meredith and King, 2005), with Martinson (2012) and Schmidtko and others (2014) reporting an increase in the delivery of warmer and saline circumpolar deep water (CDW) onto the continental shelf, heading landward through glacial canyons (Meredith and others, 2017). Over longer timescales, sea-ice extent has shown a strong negative trend on the west Antarctic Peninsula, with a moderate trend for earlier retreat in spring, and a more pronounced trend towards a later advance in autumn (Stammerjohn and others, 2008). There are, however, temporal variations with observations showing summer sea ice disappearing almost completely in 15 of the 20 years since 2000 in Ronne Entrance (sea ice remaining only in 2006, 2007, 2016, 2017 and 2020) (NSIDC Sea Ice Index, 2020).

Within the southwest Antarctic Peninsula region are four ice shelves - George VI, Stange, Bach and Wilkins - covering a total area of $\sim 49000 \mathrm{~km}^{2}$, with their drainage basins totalling $\sim 161000 \mathrm{~km}^{2}$ (Rignot and others, 2011). George VI, Stange and Bach are considered in more detail below with key attributes summarised in Table 1. Wilkins Ice Shelf is not investigated here because there are few glaciological changes observed in a preliminary study using Landsat 8 OLI imagery acquired between 2013 and 2019, and because it has recently been described elsewhere (e.g. Rankl and others, 2017).

\section{Bach Ice Shelf}

Bach Ice Shelf occupies the southern region of Alexander Island (Fig. 1a). It comprises four main flow units with a confluence near the ice front, the most dominant being Weber and Boccherini inlets. It has a spatially averaged surface flow speed of $62 \mathrm{~m} \mathrm{a}^{-1}$, with a maximum speed of $\sim 230 \mathrm{~m} \mathrm{a}^{-1}$ recorded at the grounding zone of Lovell Glacier (Fig. 1b). At the ice front, flow speeds reach a maximum of $\sim 140 \mathrm{~m} \mathrm{a}^{-1}$. Between 1947 and $2008, \sim 311 \mathrm{~km}^{2}$ of ice was lost from its front (Cook and Vaughan, 2010), but it maintained its sinusoidal-shaped ice-front geometry and covered an area of $\sim 4536 \mathrm{~km}^{2}$ in 2010 (Holt, 2012).
Holt (2012) noted extensive melt pools that fill structurally-influenced channels in the northern reaches of Weber, Boccherini and Williams inlets, and isolated pools also occur in the northern section of Stravinsky Inlet. Ice dolines in the northern extents of Boccherini and Williams inlets suggest a hydrological link between the surface and an englacial environment. Bach Ice Shelf has a mean firn thickness of $\sim 14.6 \mathrm{~m}$ (van den Broeke, 2005). Holt (2012) also observed the development of two fracture units between October and December 2004, which at the time were $\sim 9 \mathrm{~km}$ from the ice front.

\section{Stange Ice Shelf}

Stange Ice Shelf is the most southern and westerly ice shelf on the Antarctic Peninsula (Fig. 1a). It measured $\sim 7900 \mathrm{~km}^{2}$ in 2011 (Holt and others, 2014), and displayed a complex dynamic configuration owing to several glacial basins on the English Coast, Spaatz Island and Smyley Island from which tributary glaciers flow. It has three independent ice fronts, the largest (Stange North) of which calves into Ronne Entrance. Two smaller ice fronts (Stange Central and Stange South) calve into Carroll Inlet; an isolated embayment that is typically filled with fast ice. The mean flow speed for Stange Ice Shelf is $\sim 200 \mathrm{~m} \mathrm{a}^{-1}$ : The most southerly ice front is the most dynamic, fed by Landsat Ice Stream that reaches the speeds of $\sim 800 \mathrm{~m} \mathrm{a}^{-1}$ (Rignot and others, 2011) (Fig. 1b). It was here that Holt and others (2014) noted the greatest structural and dynamic changes between 2001 and 2011 including the increased presence of shear-induced fracturing between flow units.

Holt and others (2014) attributed surface elevation changes (inferred ice-shelf thinning) to an increase in basal melting, as also noted on the nearby George VI and Wilkins ice shelves (Padman and others, 2012; Holland and others, 2010), though some lowering may also result from firn compaction at its northern front. Stange Ice Shelf sits between the -11 and $-15^{\circ} \mathrm{C}$ mean annual isotherms (Morris and Vaughan, 2003) and for much of its surface area, the mean number of melt days (20062012) was $\sim 35 \mathrm{~d} \mathrm{a}^{-1}$, ranging from $\sim 80 \mathrm{~d} \mathrm{a}^{-1}$ at its northern ice front and only $10 \mathrm{~d} \mathrm{a}^{-1}$ along the English coast (Holt and others, 2014). Key attributes are presented in Table 1.

\section{George VI Ice Shelf}

George VI Ice Shelf is the second largest remaining on the Antarctic Peninsula covering an area of $\sim 23000 \mathrm{~km}^{2}$. It has two 
frontal margins situated $\sim 450 \mathrm{~km}$ apart: a northern ice front (George VI North) that calves into Marguerite Bay, with three further ice fronts located in its southern region (George VI South). The ice shelf is fed predominantly from glaciers draining Palmer Land that flow across George VI Sound and butt against Alexander Island. Occasionally these large glaciers run into smaller tributaries flowing in the opposite direction from Alexander Island, but for only a few kilometres. The glaciers from Palmer Land reach the speeds of up to $700 \mathrm{~m} \mathrm{a}^{-1}$ in the northern region and are interspersed with less active areas of ice moving at the speeds of just $10 \mathrm{~s}$ $\mathrm{m} \mathrm{a}^{-1}$ (Fig. 1b). At approximately $-68^{\circ} 8^{\prime} 0^{\prime \prime} \mathrm{W}-72^{\circ} 32^{\prime} 0^{\prime \prime} \mathrm{S}$, there is an ice-shelf divide (see Fig. 1a): Tributaries entering George VI Sound south of this flow $\sim 150 \mathrm{~km}$ towards George VI South at speeds of $\sim 300-400 \mathrm{~m} \mathrm{a}^{-1}$. Tributary glaciers GT02 to Grace Ice Stream feed the ice front located between Monteverdi Peninsula and the Eklund Islands. Further southwest, tributary glaciers GT05 to Sentinel Ice Stream feed an ice front between the Eklund Islands and DeAtley Island, with a smaller ice front fed by glaciers GT08 and GT09. These three southern fronts are dynamically independent but do form a continuous ice-shelf system in the southern region.

Widespread recession of George VI's ice fronts has been previously reported, including a loss of $\sim 1255 \mathrm{~km}^{2}$ between 1974 and 2010 from George VI North (Holt and others, 2013) and a loss of $\sim 1400 \mathrm{~km}^{2}$ between 1947 and 2008 at George VI South (Cook and Vaughan, 2010). At the southern margin, ice entering the shelf from GT05, GT06 and Sentinel Ice Stream saw a considerable increase in the speed of up to $340 \pm 38 \mathrm{~m} \mathrm{a}^{1}$ from 1989 to 2010 owing to the removal of the stabilising ice front and associated iceshelf thinning (Holt and others, 2013; Hogg and others, 2017).

Surface melting occurs regularly along its northern extent in the austral summer, with melt pools and interconnected channels forming in structurally-influenced longitudinal and transverse troughs (Reynolds and Hambrey, 1988; Holt and others, 2013; Banwell and others, 2021; Barnes and others, 2021). George VI Ice Shelf is also known to have a high basal melt rate driven by the flooding of CDW into the ice-shelf cavity (e.g. Holland and others, 2010; Fricker and Padman, 2012; Adusumilli and others, 2018). Key attributes are summarised in Table 1. Further, numerical modelling illustrates the importance of George VI Ice Shelf to future sea level rise, with Schannwell and others (2016) projecting that up to $70 \%$ of the total contribution from the Antarctic Peninsula's iceshelf tributary glaciers comes from George VI Ice Shelf alone.

\section{Data and methods}

Landsat 7 ETM+ (2005-2010), Landsat 8 OLI (2013-2020), Sentinel 2 (2016-2020) and ASTER (1999-2010) scenes were used in this study (online Supplementary Table S1). Optical images were downloaded from the USGS's Earth Explorer collection (Level 1C) via the Semi-Automatic Classification plug-in (SCP; Congedo, 2016) in QGIS 3.4. All Landsat and Sentinel 2 scenes were atmospherically corrected using a dark object subtraction method, with Landsat bands 2, 3 and 4 also pan-sharpened to $15 \mathrm{~m}$ pixel resolution using a Brovey conversion in the SCP. The single ASTER scene was only used for additional visual analysis and was not pre-processed to the same level as other data.

Ice-front positions were manually mapped to an accuracy of \pm 2 pixels in ArcGIS 10.7 at a scale of 1: 50000 for seven austral summers between 2009 and 2020 (2009/10, 2013/14, 2014/15, $2016 / 17,2017 / 18,2018 / 19,2019 / 20)$, taking advantage of the finest available Landsat $\left(15 \mathrm{~m} \mathrm{pixel}^{-1}\right)$ and Sentinel $2\left(10 \mathrm{~m} \mathrm{pixel}^{-1}\right)$ visible bands. Ice-shelf areal loss and gain were calculated between each austral summer studied, and for the full observation period. Uncertainty analysis was conducted on Bach Ice Shelf, whereby its frontal position and subsequent area change was mapped three times for each year. This analysis revealed that uncertainty in area change was at most $\pm 0.5 \mathrm{~km}^{2}$ - a fraction of the ice-shelf area change recorded between time periods.

Structural assessment for all three ice shelves was conducted for the austral summers 2009/10, 2013/14 and 2019/20 using cloud-free Landsat ETM+, Landsat OLI and Sentinel 2 scenes; visual analysis of intervening years suggested only minor changes had occurred, so we opted to quantify changes over a 4-6 year timescale. Additional analysis of Bach Ice Shelf was undertaken using Landsat ETM+ and ASTER imagery acquired between 2001 and 2005 to show the development of two distinctly large fractures first noted by Holt (2012). Our quantitative structural analysis focused on the lengths and widths of open fractures on Bach, Stange and George VI. We define 'open fractures' as those that have a clear, sharp boundary between the fracture edge and the surrounding ice shelf for all or part of its length. If the chasm was sufficiently wide, smooth sea ice, a melange of calved blocks and sea ice, or open water was visible within the fracture. We first measured open fracture length from tip to tip along its centreline, then measured the widest part of the open fracture orthogonal to the centreline. We did not quantify fractures that were infilled with snow, or considered to be the surface expression of basal crevasses due to difficulties in measuring their width. These 'smooth' fractures are no less important and were instead considered in a qualitative analysis as part of the wider discussion.

We calculated flow fields for 2019/20 using a Fourier-based 'co-registration of optically sensed images and correlation' approach (COSI-Corr; Leprince and others, 2007). COSI-Corr is an add-in for ENVI Classic (available as part of the ENVI 5.5 package), which was developed for use in geosciences. It allows retrieval of sub-pixel displacements between good quality optical images and is one of the most robust methods for calculating glacier flow (Heid and Kääb, 2012). Flow speeds were calculated for all of Bach and Stange ice shelves, whereas for George VI Ice Shelf only the two frontal regions were considered as prior investigations (e.g. Holt and others, 2013) illustrated that structural and dynamic changes were focused in these areas only. For each ice shelf, we selected near cloud-free Landsat 8 scenes from February 2019 as the $t_{0}$ image, and a second Landsat 8 scene from October to December 2019 or January 2020 as our $t_{1}$ image. We used scenes from the same path and row for $t_{0}$ and $t_{1}$ to reduce geometric uncertainty in our results. For each image pair, a range of initial (pixel displacement) and final window (sub-pixel displacement) sizes were chosen, guided by expected displacement between images, with the smoothest (i.e. containing less noise) flow field output chosen. Input parameters and flow field output information are shown in Table 2. We then converted displacement from $\mathrm{m} \mathrm{t}_{0}-\mathrm{t}_{1}^{-1}$ to $\mathrm{m} \mathrm{a}^{-1}$. Given the nature of the terrain under investigation, there was limited opportunity to calculate absolute error from regions of stable bare ground, as is common practice with such feature tracking approaches. Instead, we estimate uncertainty of our flow speed calculations to be no more than 1 pixel $\left(15 \mathrm{~m} \mathrm{t}_{0}-\mathrm{t}_{1}^{-1}\right)$ given the retrieval of sub-pixel displacements via the COSI-Corr method, and relatively flat terrain of an ice-shelf surface that is void of large topographic variations that can introduce substantial errors. We are confident that our uncertainties (metres) are far lower than calculated flow speeds for each ice shelf (tens to hundreds of metres).

\section{Results}

\section{Ice-shelf areal loss and gain}

All three ice shelves recorded areal loss from 2009/10 and 2019/20 (Table 3). Spatial (Fig. 2) and temporal (Fig. 3) patterns varied considerably. Bach Ice Shelf underwent sustained recession along its ice front in each of the time periods, with a total of $120.6 \mathrm{~km}^{2}$ ice lost at a net rate of $-11.8 \mathrm{~km}^{2} \mathrm{a}^{-1}$. Its frontal 
Table 2. Key input parameters for COSI-Corr feature tracking processes and resulting pixel resolution

\begin{tabular}{|c|c|c|c|c|c|c|c|c|}
\hline Ice shelf & $\begin{array}{c}\text { Landsat } \\
8 \text { path/row }\end{array}$ & $\begin{array}{c}t_{0} \text { date } \\
\text { (DD/MM/YYYY) }\end{array}$ & $\begin{array}{c}\mathrm{t}_{1} \text { date } \\
(\mathrm{DD} / \mathrm{MM} / \mathrm{YYYY})\end{array}$ & $\mathrm{t}_{1}-\mathrm{t}_{0}$ (days) & $\begin{array}{l}\text { Initial search } \\
\text { window (pixels) }\end{array}$ & $\begin{array}{c}\text { Final search } \\
\text { window (pixels) }\end{array}$ & $\begin{array}{l}\text { Step size } \\
\text { (pixels) }\end{array}$ & $\begin{array}{c}\text { Output image } \\
\text { pixel resolution }(\mathrm{m})\end{array}$ \\
\hline Bach & $219 / 111$ & $06 / 02 / 2019$ & 07/12/2019 & 304 & 256 & 256 & 8 & 240 \\
\hline Stange & $\begin{array}{l}221 / 111 \\
221 / 112\end{array}$ & $20 / 02 / 2019$ & 05/12/2019 & 288 & 256 & 128 & 4 & 120 \\
\hline George VI (South 1) & $219 / 112$ & $06 / 02 / 2019$ & $07 / 12 / 2019$ & 304 & 128 & 128 & 2 & 60 \\
\hline George VI (South 2) & $\begin{array}{l}218 / 111 \\
218 / 112\end{array}$ & $15 / 02 / 2019$ & 29/10/2019 & 256 & 256 & 8 & 2 & 60 \\
\hline George VI (North) & $218 / 109$ & $06 / 02 / 2019$ & $17 / 01 / 2020$ & 346 & 256 & 8 & 2 & 60 \\
\hline
\end{tabular}

The initial search window calculates pixel displacement, with the final search window used to look for sub-pixel displacements. Step size determines the step (in pixels) that each window will move in an $x$ and $y$ direction during correlation. George VI (South 1) represents the location between Monteverdi Peninsula and the Eklund Islands. George VI (South 2) represents the location between the Eklund Islands and DeAtley Island. Both locations are covered by different Landsat footprints (path/row).

Table 3. Areal gain and loss for each ice front and total ice-shelf area for the six time periods studied

\begin{tabular}{|c|c|c|c|c|c|c|c|c|}
\hline Ice shelf & Measurement & $2009 / 10-2013 / 14$ & 2013/14-2014/15 & $2014 / 15-2016 / 17$ & $2016 / 17-2017 / 18$ & $2017 / 18-2018 / 19$ & $2018 / 19-2019 / 20$ & $2009 / 10-2019 / 20$ \\
\hline \multirow[t]{4}{*}{ Bach } & Gain $\left(\mathrm{km}^{2}\right)$ & 0.0 & 0.3 & 2.7 & 0.4 & 0.0 & 1.3 & 0.0 \\
\hline & Loss $\left(\mathrm{km}^{2}\right)$ & 56.4 & 13.6 & 9.5 & 12.6 & 22.2 & 9.6 & 120.6 \\
\hline & Net change $\left(\mathrm{km}^{2}\right)$ & -56.4 & -13.3 & -6.9 & -12.2 & -22.2 & -8.2 & -120.6 \\
\hline & Net rate $\left(\mathrm{km}^{2} \mathrm{a}^{-1}\right)$ & -13.9 & -11.0 & -3.6 & -13.2 & -19.5 & -8.6 & -11.8 \\
\hline \multirow[t]{4}{*}{ Stange North } & Gain $\left(\mathrm{km}^{2}\right)$ & 1.5 & 5.7 & 8.2 & 8.2 & 4.5 & 5.7 & 0.8 \\
\hline & Loss $\left(\mathrm{km}^{2}\right)$ & 111.4 & 17.1 & 20.5 & 6.8 & 21.4 & 10.4 & 156.9 \\
\hline & Net change $\left(\mathrm{km}^{2}\right)$ & -109.9 & -11.3 & -12.3 & 1.4 & -16.9 & -4.8 & -156.1 \\
\hline & Net rate $\left(\mathrm{km}^{2} \mathrm{a}^{-1}\right)$ & -27.9 & -10.1 & -6.0 & 1.3 & -17.5 & -5.2 & -15.6 \\
\hline \multirow[t]{4}{*}{ Stange Central } & Gain $\left(\mathrm{km}^{2}\right)$ & 17.3 & 7.1 & 8.5 & 8.0 & 10.2 & 10.0 & 22.8 \\
\hline & Loss $\left(\mathrm{km}^{2}\right)$ & 9.2 & 15.2 & 43.7 & 15.2 & 3.7 & 9.9 & 59.1 \\
\hline & Net change $\left(\mathrm{km}^{2}\right)$ & 8.1 & -8.1 & -35.2 & -7.2 & 6.5 & 0.1 & -36.3 \\
\hline & Net rate $\left(\mathrm{km}^{2} \mathrm{a}^{-1}\right)$ & 2.0 & -7.2 & -17.3 & -6.8 & 6.8 & 0.1 & -3.6 \\
\hline \multirow[t]{4}{*}{ Stange South } & Gain $\left(\mathrm{km}^{2}\right)$ & 32.4 & 0.0 & 10.2 & 8.8 & 7.4 & 8.4 & 18.2 \\
\hline & Loss $\left(\mathrm{km}^{2}\right)$ & 1.5 & 66.3 & 1.0 & 0.3 & 1.3 & 0.6 & 22.2 \\
\hline & Net change $\left(\mathrm{km}^{2}\right)$ & 30.9 & -66.3 & 9.2 & 8.4 & 6.1 & 7.9 & -4.0 \\
\hline & Net rate $\left(\mathrm{km}^{2} \mathrm{a}^{-1}\right)$ & 7.8 & -59.2 & 4.5 & 8.0 & 6.3 & 8.6 & -0.4 \\
\hline \multirow[t]{4}{*}{ Stange Total } & Gain $\left(\mathrm{km}^{2}\right)$ & 51.2 & 12.8 & 26.8 & 25.0 & 22.2 & 24.1 & 41.8 \\
\hline & Loss $\left(\mathrm{km}^{2}\right)$ & 122.1 & 98.6 & 65.1 & 22.4 & 26.4 & 20.9 & 238.2 \\
\hline & Net change $\left(\mathrm{km}^{2}\right)$ & -70.9 & -85.8 & -38.3 & 2.6 & -4.3 & 3.2 & -196.4 \\
\hline & Net rate $\left(\mathrm{km}^{2} \mathrm{a}^{-1}\right)$ & -18.0 & -76.6 & -18.8 & 2.5 & -4.4 & 3.5 & -19.6 \\
\hline \multirow[t]{4}{*}{ George VI South } & Gain $\left(\mathrm{km}^{2}\right)$ & 21.2 & 20.8 & 30.0 & 36.6 & 43.3 & 43.8 & 54.9 \\
\hline & Loss $\left(\mathrm{km}^{2}\right)$ & 430.4 & 90.0 & 97.8 & 30.5 & 12.2 & 26.3 & 552.1 \\
\hline & Net change $\left(\mathrm{km}^{2}\right)$ & -409.2 & -69.2 & -67.8 & 6.1 & 31.1 & 17.5 & -497.2 \\
\hline & Net rate $\left(\mathrm{km}^{2} \mathrm{a}^{-1}\right)$ & -99.3 & -68.7 & -32.9 & 5.1 & 44.4 & 16.7 & -49.1 \\
\hline \multirow[t]{4}{*}{ George VI North } & Gain $\left(\mathrm{km}^{2}\right)$ & 9.5 & 6.3 & 12.4 & 5.9 & 8.3 & 5.4 & 32.4 \\
\hline & Loss $\left(\mathrm{km}^{2}\right)$ & 14.5 & 1.1 & 1.1 & 0.8 & 1.5 & 9.9 & 15.7 \\
\hline & Net change $\left(\mathrm{km}^{2}\right)$ & -5.0 & 5.2 & 11.3 & 5.1 & 6.8 & -4.5 & 16.7 \\
\hline & Net rate $\left(\mathrm{km}^{2} \mathrm{a}^{-1}\right)$ & -1.3 & 4.7 & 5.4 & 6.2 & 6.1 & -4.8 & 1.7 \\
\hline \multirow[t]{4}{*}{ George VI Total } & Gain $\left(\mathrm{km}^{2}\right)$ & 30.6 & 27.1 & 42.4 & 42.5 & 51.6 & 49.1 & 87.3 \\
\hline & Loss $\left(\mathrm{km}^{2}\right)$ & 444.9 & 91.1 & 98.9 & 31.3 & 13.7 & 36.1 & 567.8 \\
\hline & Net change $\left(\mathrm{km}^{2}\right)$ & -414.2 & -64.0 & -56.5 & 11.2 & 37.9 & 13.0 & -480.5 \\
\hline & Net rate $\left(\mathrm{km}^{2} \mathrm{a}^{-1}\right)$ & -100.6 & -64.0 & -27.5 & 11.4 & 50.4 & 11.9 & -47.4 \\
\hline
\end{tabular}

Final column gives total change from 2009/10 to 2019/20.

geometry became increasingly concave as it decoupled from its Monteverdi Peninsula pinning point in the east. Stange North recorded a total loss of $156.1 \mathrm{~km}^{2}$ between $2009 / 10$ and $2019 / 20$ at a rate of $-36.6 \mathrm{~km} \mathrm{a}^{-1}$, though $-109.9 \mathrm{~km}^{2}$ of this was lost between 2009/10 and 2013/14 alone. Stange Central and Stange South recorded little overall change $\left(-3.6\right.$ and $-0.4 \mathrm{~km}^{2}$ respectively).

George VI North saw sustained advance over much of its length, with loss only recorded at its western margin where a sizable polynya was observed in each of the measurement periods. In total, George VI North saw a net gain of $16.7 \mathrm{~km}^{2}$ from 2009/10 to $2019 / 20$. George VI South recorded the largest net change $\left(-497.2 \mathrm{~km}^{2}\right)$ between $2009 / 10$ and 2019/20, but again most of this loss occurred between 2009/10 and 2013/14, concentrated between Monteverdi Peninsula and the Eklund Islands. In 2016/17, $2017 / 18$ and 2019/20, George VI South recorded net gains of +5.1 , +44.4 and $+16.7 \mathrm{~km}^{2}$ respectively (Table 3 ). In total, the three ice shelves had a net change of $-797.5 \mathrm{~km}^{2}$ from $2009 / 10$ to $2019 / 20$.

\section{Ice-shelf flow speed}

Bach Ice Shelf s flow regime is dominated by glaciers entering and flowing through Boccherini Inlet to the ice front (Fig. 4a). Flow speeds in its central portion reached $\sim 150 \mathrm{~m} \mathrm{a}^{-1}$ during 2019/20, $\sim 40 \mathrm{~m} \mathrm{a}^{-1}$ faster than reported in the MEaSUREs velocity data (hereafter referred to as 'ca. 2008'; taken from Rignot and others, 2011) (Fig. 5a).

Stange Ice Shelf has a complex flow regime, with tributaries entering the ice shelf from catchments on Smyley Island, Spaatz Island and the English Coast, the latter of which has the greatest contribution. Stange North is fed by ice flowing from all three catchments, Stange Central is fed by tributaries from Smyley and the English Coast, and Stange South is fed only by ice flowing from the English Coast. Tributaries ST03, ST04 and the Lidke Ice Stream (Fig. 4b) are responsible for the fastest flow in the main portion of the ice shelf $\left(\sim 450 \mathrm{~m} \mathrm{a}^{-1}\right)$. The fastest flow speeds on the ice shelf are found in the Landsat Ice Stream $\left(\sim 750 \mathrm{~m} \mathrm{a}^{-1}\right)$ 


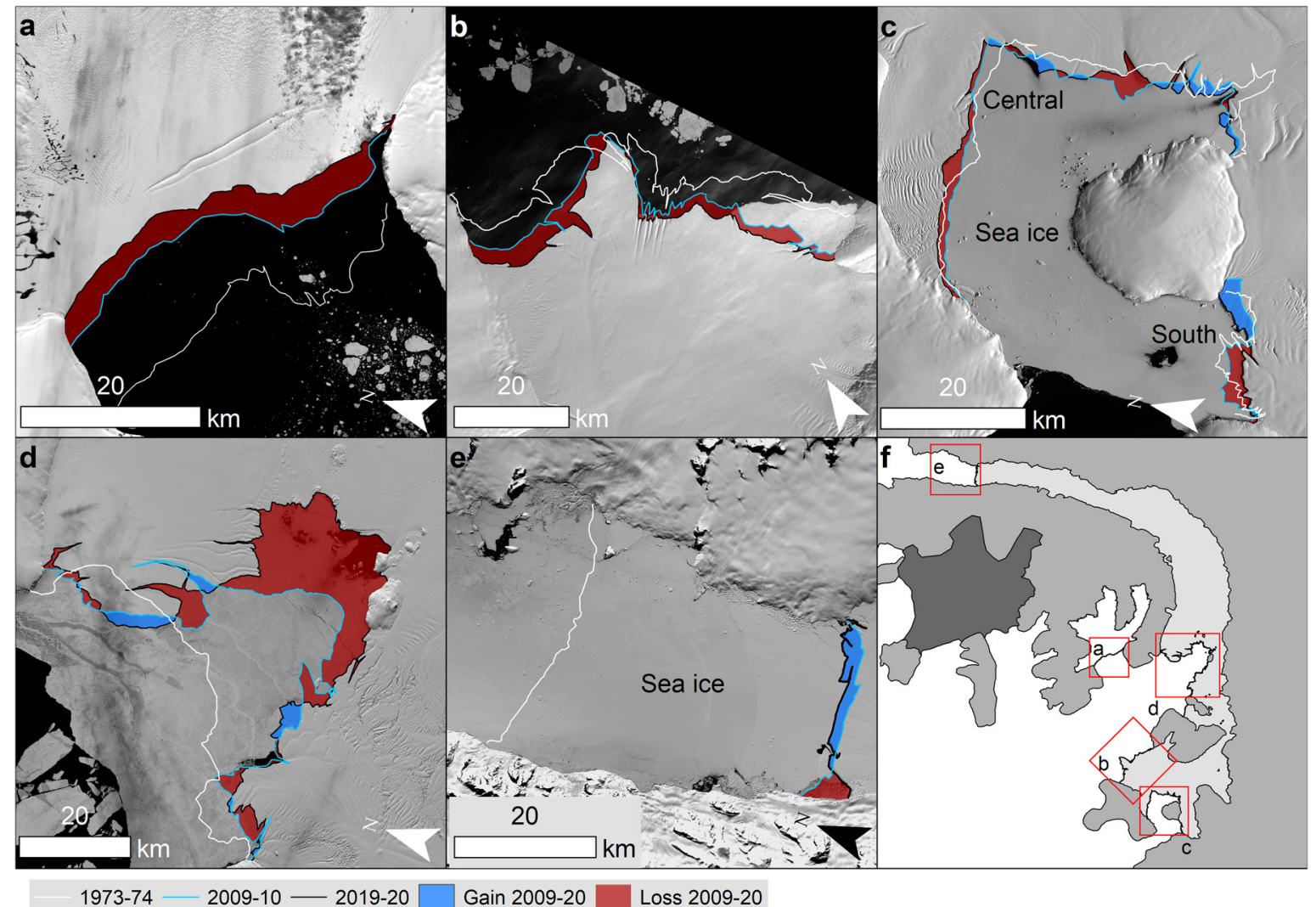

Fig. 2. Ice-front changes observed between $2009 / 10$ and 2019/20. Earliest recorded ice-front position in the satellite era is shown for comparative purposes (1973/ 74, taken from Holt, 2012). (a) Bach Ice Shelf; note the 'sinusoidal' shape to its ice-front geometry that becomes less distinct with time. (b) Stange North; note the prominent area that juts out in the centre of the ice front. (c) Stange Central and Stange South. (d) George VI South. (e) George VI North. (f) Extent indicators of panels (a-e).

that feeds Stange South. There is little observed change in flow speeds across the main portion of Stange Ice Shelf between ca. 2008 and 2019/20 (Fig. 5b), but speeds on Landsat Ice Stream have decreased by $\sim 120 \mathrm{~m} \mathrm{a}^{-1}$.

The calving front of George VI North is dominated by flow from Riley Glacier (Fig. 4e). At its grounding zone, flow speeds measure $\sim 600 \mathrm{~m} \mathrm{a}^{-1}$, decreasing to $\sim 300 \mathrm{~m} \mathrm{a}^{-1}$ at the calving front over a straight-line distance of $\sim 20 \mathrm{~km}$. Further downstream ( $\sim 25 \mathrm{~km}$ from the ice front), Skinner and Chapman glaciers converge on Palmer Land and enter the ice shelf as one flow unit at the speeds of $\sim 500 \mathrm{~m} \mathrm{a}^{-1}$, slowing to $\sim 150 \mathrm{~m} \mathrm{a}^{-1}$ within $\sim 10 \mathrm{~km}$. Speeds decrease further towards Alexander Island, reaching only a few tens of $\mathrm{m} \mathrm{a}^{-1}$. We observe an increase in flow speed along the centreline of Riley Glacier from ca. 2008 to 2019/20 (Fig. 5c), ranging from $+100 \mathrm{~m} \mathrm{a}^{-1}$ near the grounding zone (from 0 to $10 \mathrm{~km}$ along the transect) to $+40 \mathrm{~m} \mathrm{a}^{-1}$ between 10 and $23 \mathrm{~km}$ along the transect. At its ice front, flow speeds have increased by $\sim 50 \mathrm{~m} \mathrm{a}^{-1}$ since ca. 2008.

The southern portion of George VI Ice Shelf is controlled by glaciers entering from the English Coast. Between the Eklund Islands and DeAtley Island, GT05, GT06 and the Sentinel Ice Stream feed the most dynamic part of the ice shelf. Here, at the centre of its calving front, flow speeds reach $\sim 900 \mathrm{~m} \mathrm{a}^{-1}$. Speeds along the centreline of Sentinel Ice Stream increased by $\sim 80 \mathrm{~m} \mathrm{a}^{-1}$ since ca. 2008 (Fig. 5c). Between Monteverdi Peninsula and the Eklund Islands, flow ranges from $<100 \mathrm{~m} \mathrm{a}^{-1}$ around the numerous ice rises and ice rumples, to $\sim 420 \mathrm{~m} \mathrm{a}^{-1}$ at the centre of the ice front. Ice here is derived from glaciers that enter the shelf about $150 \mathrm{~km}$ further upstream (see Fig. $1 \mathrm{~b}$ for wider perspective). There is little change in flow speed observed between ca. 2008 and 2019/20 in this location (Fig. 5c).

\section{Ice-shelf surface structural assessment}

Open fracture lengths and widths were measured for each ice shelf for the austral summers of 2009/10, 2013/14 and 2019/20 (Figs 6-8; Table 4). Few open fractures were observed on Bach Ice Shelf in the three periods, yet the area immediately behind the ice front is dominated by two long fracture sets. Further analysis revealed that these became visible at the surface between October and December 2004 (Figs 7a-f). Since 2004, both fracture sets have increased in length and width as they moved towards the receding ice front. The most northly of these (furthest from the ice front) saw the greatest increase in width from $\sim 85 \mathrm{~m}$ in $2009 / 10$ to $\sim 350 \mathrm{~m}$ in $2019 / 20$, at which point they both measured $>21 \mathrm{~km}$ in length. In recent imagery, the opening of the widest fracture displays a smooth surface with no evidence of liquid water or calved blocks at $10 \mathrm{~m}$ pixel resolution. Other open fractures on Bach Ice Shelf are transient in nature, cutting back into the shelf from the calving front for a maximum of $3 \mathrm{~km}$ in length and $350 \mathrm{~m}$ in width.

The number of open fractures increased on Stange Ice Shelf in each of the measurement periods. Of note is a rise in open fracture lengths measuring $500-999 \mathrm{~m}$ and $+5000 \mathrm{~m}$, and a particularly noticeable increase in fracture widths measuring 100-199 $\mathrm{m}$ and $250-299 \mathrm{~m}$ (Figs 6a-b). There was a small decrease in the frequency of open fracture widths measuring $+500 \mathrm{~m}$ in both 2013/14 and again in 2019/20. Cumulative frequency curves (Figs 6a-b) show a greater proportion of open fractures measuring < $1999 \mathrm{~m}$ in length in 2019/20 than both 2013/14 and $2009 / 10$, but a greater proportion of fracture widths measuring more than $149 \mathrm{~m}$ in 2019/20. Wider open fractures were measured at the grounding zone of Spaatz Island and at the southern edge of Stange Central (Figs $7 \mathrm{~d}-\mathrm{f}$ ). 


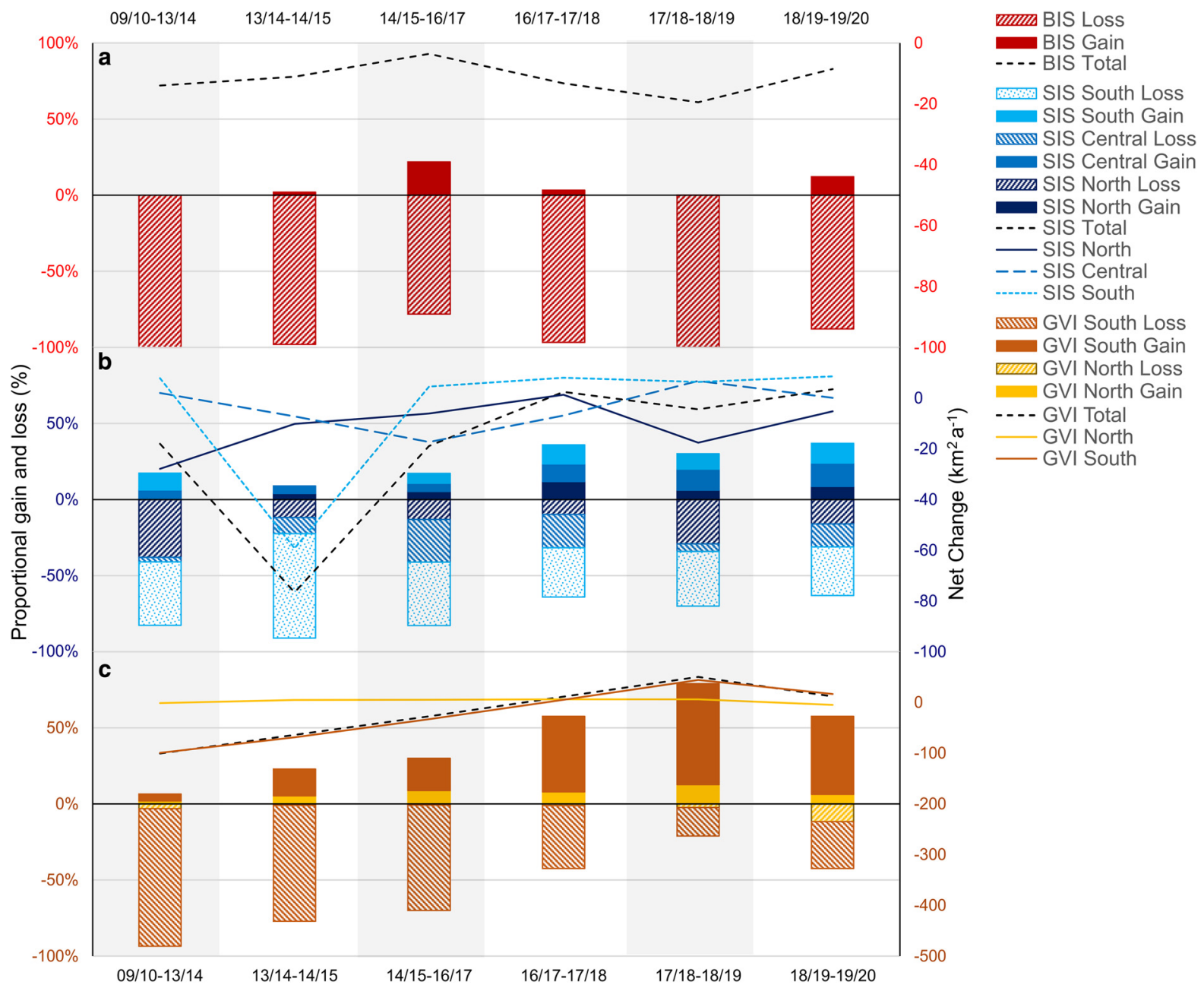

Fig. 3. Proportional area gain and loss (left-hand axis) and net change (right-hand axis) for each ice shelf (and ice front) in the six time periods observed in this study. Each column $=100 \%$ total. (a) Bach Ice Shelf (BIS); note persistent areal loss with only minor gain noted in four of the six periods. (b) Stange Ice Shelf (SIS); note greater loss in the first three periods than the last three. (c) George VI Ice Shelf (GVI); note (i) GVI South recorded loss in the first three time periods, followed by three periods of gain, (ii) GVI North recorded slight increases in four of the six periods, with net loss recorded in 09/10-13/14 and 18/19-19/20 only.

A greater number of open fractures were also measured along Stange North (Figs $7 \mathrm{~d}-\mathrm{f}$ ) with clustering around the prominent ice-front portion that juts out into Ronne Entrance. The southern region of Stange Ice Shelf saw a reduction in open fractures at both its calving front and in the area occupied by shear-induced fractures in 2010 (see Holt and others, 2014). Of those fractures sufficiently wide to see inside their chasms, all are filled by either smooth ice or melange; no areas of open water were observed unless the open fractures were positioned at an ice front.

At George VI North, open fractures were clustered at its eastern pinning point, with individual features observed infrequently along the rest of its calving front. Within this cluster, the fractures became increasingly long and wide throughout the measurement periods (Figs $8 \mathrm{a}-\mathrm{c}$ ). Liquid water, small, calved blocks and smooth ice were observed in open fractures wide enough to see the base of their chasms.

Fractures are widespread across the southern region of George VI Ice Shelf (Figs 8d-f) and are particularly chaotic in places, often containing calved toppled and tabular icebergs, melange, and some pockets of open water, even near the grounding zone. Between Monteverdi Peninsula and the Eklund Islands, the number of open fractures increased from 35 to 61 between 2009/10 and 2013/14, before decreasing to 32 by $2019 / 20$. In 2013/14, clusters of small open fractures were observed lee-side of the Eklund Island ice rumples and account for the observed decrease in the mean fracture length (from $3074 \mathrm{~m}$ in $2009 / 10$ to $2198 \mathrm{~m}$ ) and fracture width (from 422 to $234 \mathrm{~m}$ ). By 2019/20, a succession of open fractures with wide chasms was observed stemming from the most northerly Eklund Island ice rumple. These features formed a distinctly jagged ice front. The mean open fracture lengths and widths in 2019/20 were 4220 and $289 \mathrm{~m}$, respectively.

Between the Eklund Islands and DeAtley Island, the number of open fractures increased from 112 (2009/10) to 198 (2013/ 14) to $205(2019 / 20)$. Mean open fracture lengths $(2095,1702$, $2093 \mathrm{~m}$ respectively) and widths (323, 186, $217 \mathrm{~m}$ respectively) were relatively consistent, though a cluster of open fractures west of the largest of the Eklund Islands noticeably increased in length and width between 2009/10 and 2019/20 (Figs 8d-f). In the widest of fractures, smooth sea ice and rough ice melange were observed.

Figures $6 c-d$ illustrate open fracture length and widths for all of George VI Ice Shelf as discussed above, confirming that $~ 90 \%$ of open fractures were $<3999 \mathrm{~m}$ in length and $80 \%<199 \mathrm{~m}$ in width.

\section{Interpretation and discussion}

\section{Bach Ice Shelf}

Of the three ice shelves studied, only the front of Bach showed net loss in each of the six time periods. Subtle and discrete episodes of 


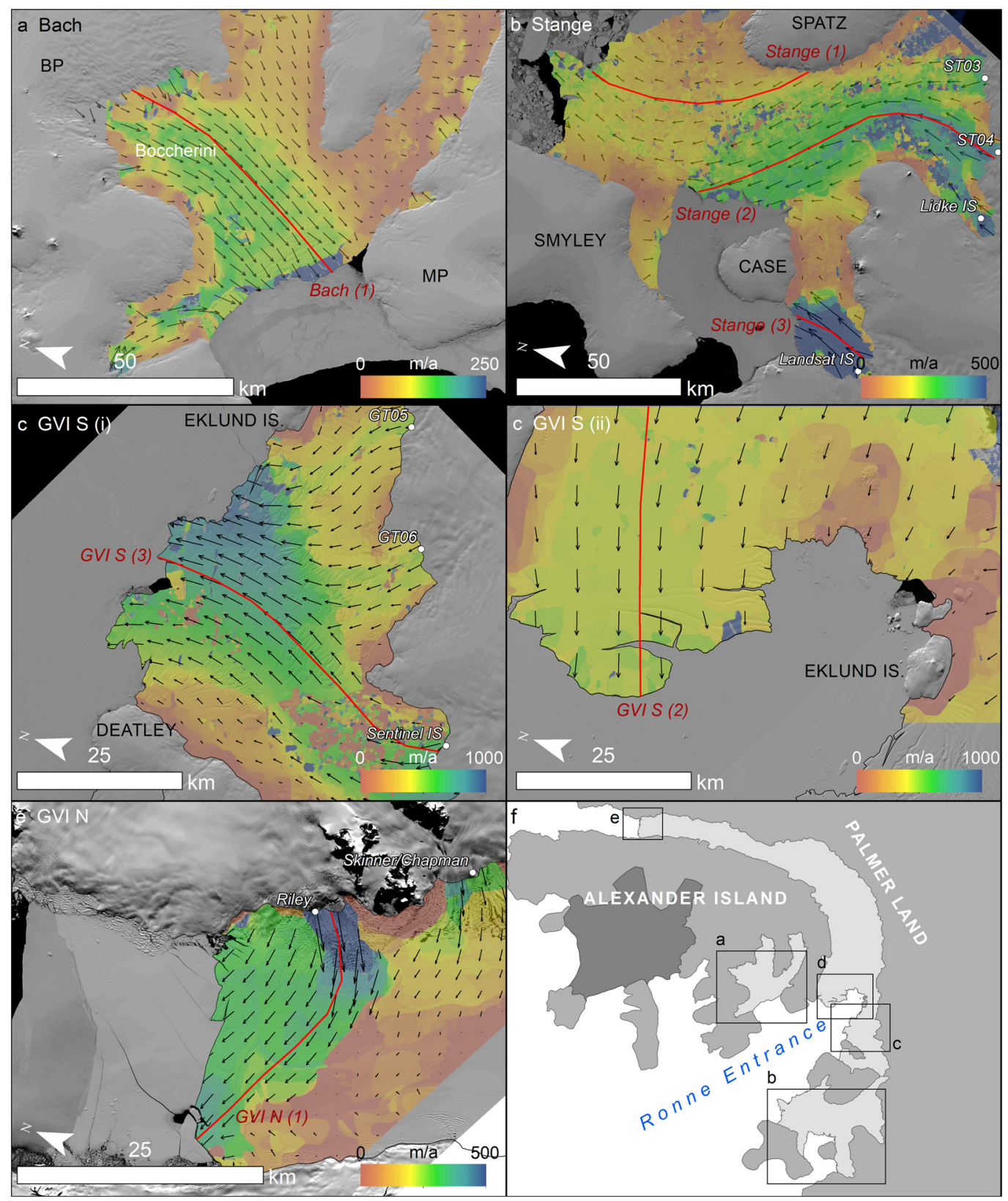

Fig. 4. 2019/20 flow speeds calculated using optical image feature tracking (see Table 2 for parameters). (a) Bach. (b) Stange. (c) George VI South (Eklund Islands to DeAtley Island). (d) George VI South (Monteverdi Peninsula to Eklund Islands). (e) George VI North. Red lines are transects shown in Figure 5. (f) Extent indicators of panels (a-e). Note that the colour ramp scale differs in each panel.

calving were observed along transient fractures at the ice front. Frontal recession led to localised decoupling of the ice shelf from its Monteverdi Peninsula pinning point in the mid-to-late 2000s, and left the front occupying a wider channel than at any other time in the satellite era.

Our analysis indicates widespread acceleration of ice flowing through Boccherini Inlet between ca. 2008 and 2019/20 (Fig. 5). We propose that ice-front recession, and particularly the decoupling from Monteverdi Peninsula, enabled flow to speed up, enhancing longitudinal tensile stresses, which may also explain the rapid appearance of the two fractures in 2004 and their subsequent expansion (Figs 9a-d)

Doake and others (1998), who investigated the role of a convex calving front in ice-shelf stability following the disintegration of Larsen A Ice Shelf in 1995 and enhanced calving of Larsen B in 1996, illustrated that a convex ice front provided a 'compressive arch', that once removed, permitted enhanced calving. Since 1973, Bach's ice front became increasingly concave along its length (Fig. 2a). Two large fracture sets developed in 2004 and gradually increased in length and width as they migrated towards the receding ice front. Owing to their geometry, calving along these fractures would undoubtedly remove the last remaining convex portion from the calving front, leaving a concave geometry across its length that may lead to further instabilities.

\section{Stange Ice Shelf}

Despite a net loss of $156.1 \mathrm{~km}^{2}$ between 2009/10 and 2019/20, Stange North's ice front maintained its distinct convex ice-front geometry. However, the prominent area that juts out into Ronne Entrance reduced in size and is now bounded on both sides by larger and wider fractures extending deeper into the ice shelf (Figs 9g-h). Further propagation of any of these fractures (labelled A-D in Figs 9g-h) will likely cause calving of this prominent area. While the overall ice-front geometry should remain 


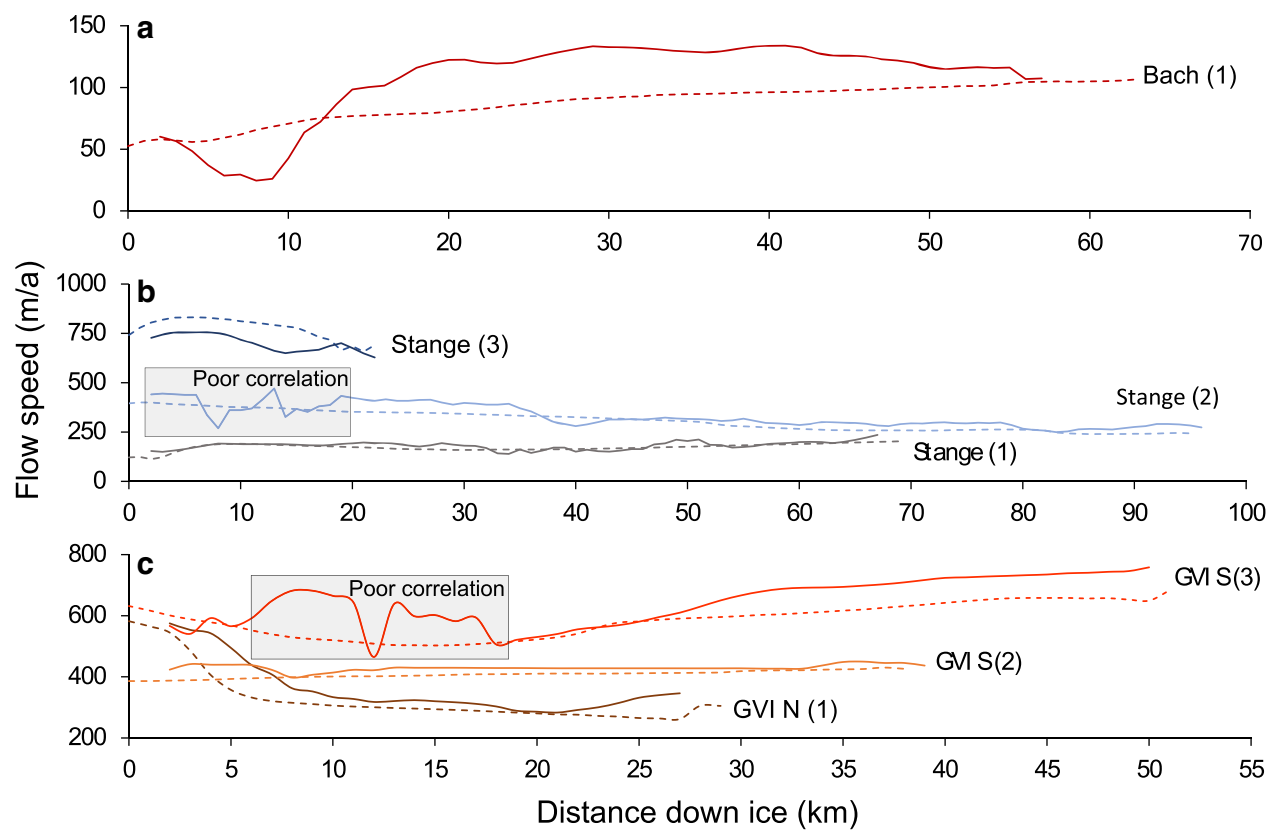

Fig. 5. Flow speeds for 2019/20 (solid lines) and ca. 2008 (MEaSUREs; Rignot and others, 2011; dashed lines) for transects shown in Figure 4. Note $y$-axis has different scales in each panel. (a) Increase in flow speeds in the central portion of Bach Ice Shelf. (b) Decrease in flow speeds along Stange (3; Stange South), with little change noted along Stange (1) and Stange (2). Note region of poor image correlation between images from 1 to $20 \mathrm{~km}$ for Stange (2). (c) Increase in flow speed along GVI S (3) from $27 \mathrm{~km}$, and GVI N (1) between 0-10 km and 22-26 km. Note region of poor correlation between images from 6 to $18 \mathrm{~km}$ for GVI S (3).

largely convex following any calving events, the profile of the ice front would be substantially altered.

At Stange Central (Figs 9i-j), ice moves atypically across the calving front, rather than towards to it. Consequently, it experiences compressive stresses as the dominant flow units from the English Coast butt against ice fed from Smyley Island that flows in the opposite direction. This perhaps explains why this area of the ice shelf shows few open fractures. That said, calving was observed in our measurement period along transient fractures, and in total a net loss of $36.3 \mathrm{~km}^{2}$ was recorded between 2009/ 10 and 2019/20, concentrated between 2014 and 2017. We suggest that the absence of sea ice in Carroll Inlet during these years allowed icebergs to calve. In the satellite era, Carroll Inlet has mostly been filled with multi-annual ice. Both in this study, and that of Holt and others (2014), it was sometimes difficult to delineate the ice front, owing to a smooth transition from fast ice to shelf ice east of Case Island. However, in this study, we observed sea ice to be less extensive. In December 2015 and January 2017, Carroll Inlet contained only a fraction of its usual sea-ice coverage, coinciding with the greatest net loss of ice from its central ice front. It has long been recognised that the presence of extensive $(10 \mathrm{~s}-100 \mathrm{~s} \mathrm{~km})$ sea ice in front of marine terminating ice masses reduces calving potential by enhancing back-stresses (e.g. Reeh and others, 2001; Robel, 2017) and by dampening waves and oceanic swell that may otherwise prompt fracturing and subsequent iceberg calving (Bromirski and others, 2010). Thus, removal of sea ice permits iceberg calving to intensify, as appears to be the case here.

We also observed three previously unseen polynyas at the ice front of Stange Central (Fig. 9j). Their positions appear related to extensive surface troughs visible in the satellite imagery, and which are likely to be related to basal channels (as a result of hydrostatic equilibrium). Here we hypothesise a process whereby warmer CDW encounters the base of the ice shelf and enhances melt (Padman and others, 2012; Holt and others, 2014). The warm, fresher water is buoyant, and flows some distance through subsurface meltwater channels from deep beneath the ice-shelf cavity, inducing further melt as it approaches the ice front.
When the sea ice in Carroll Inlet is less extensive, as it has been in recent years, the warm water possesses sufficient residual heat to melt through to form polynyas, a process which has been observed elsewhere in Antarctica (e.g. Bindschadler and others, 2011; Mankoff and others, 2012). If sea ice continues to decline in extent and/or thickness, then polynyas could become a persistent feature in Carroll Inlet, and have the potential to alter local stress regimes at the ice front to increase calving potential. Furthermore, the basal meltwater channels have formed elongated 'rifts' at the ice front that themselves may become iceberg calving boundaries as they lengthen and widen.

Stange South remains the most dynamic region of the ice shelf in terms of flow speed and calving regime. The eastern half, adjacent to Case Island, advanced $\sim 1.5 \mathrm{~km}$ from $2009 / 10$ to $2019 / 20$. Over the same period, the western portion receded $\sim 1.8 \mathrm{~km}$, although a maximum recorded recession of $\sim 6.7 \mathrm{~km}$ occurred between 2013/14 and 2014/15 in a single calving event, before advancing again in subsequent years.

Holt and others (2014) noted a reduction in flow speeds at Stange South between ca. 1989 and ca. 2010, except for a distinct shear zone in the eastern portion where a localised increase was observed. Here, we find a further reduction in flow speed across the whole of Stange South. Our structural assessment also shows that shear-induced fracturing along the eastern boundary of Stange South has all but ceased. Those fractures that propagated between 2001 and 2009 (see Holt and others, 2014, Fig. 4) began to heal under increasing compressive stresses as the ice neared Case Island. The shear fractures also began to migrate westwards across Stange South (Figs 9k-1); a response that has been noticed previously between ca. 1973 and ca. 2001 (Holt and others, 2014), and may represent long-term cyclical patterns that operate over timescales greater than the length of current satellite data record.

Analysing the grounded portion of Stange's flow units, Hogg and others (2017) reported decreasing discharge of Landsat Ice Stream and its neighbouring unnamed flow unit from $\sim 9.9$ to $8.5 \mathrm{~km}^{3} \mathrm{a}^{-1}$ and 9.4 to $8.2 \mathrm{~km}^{3} \mathrm{a}^{-1}$ respectively, between $1995 / 96$ and 2014/16. There are two probable scenarios here to explain the decrease: 


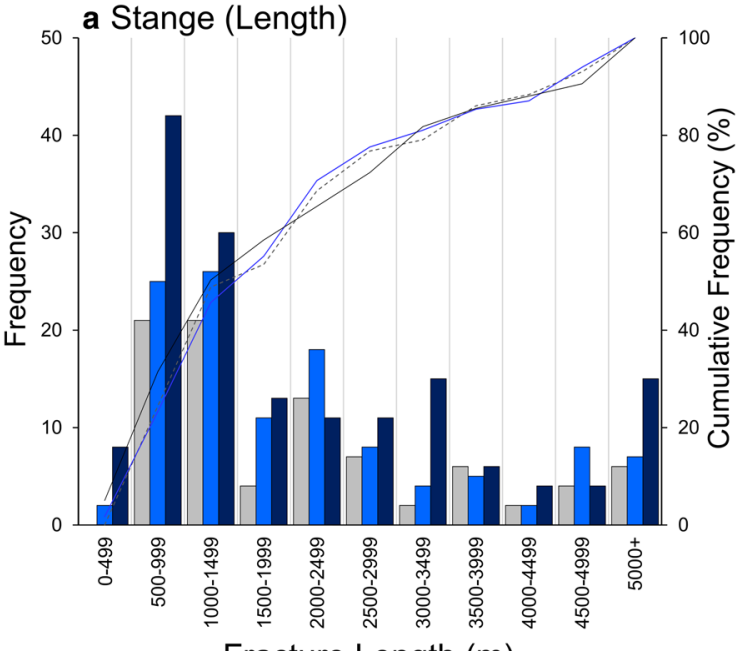

Fracture Length $(\mathrm{m})$

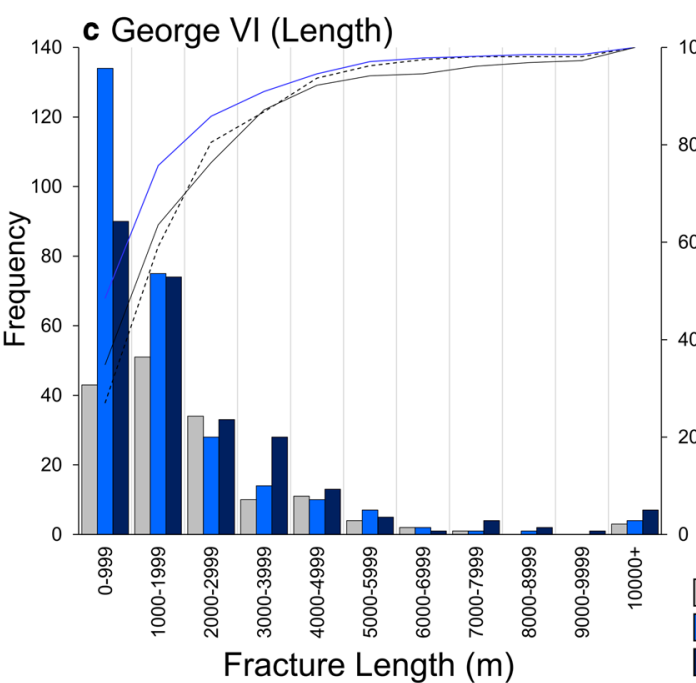

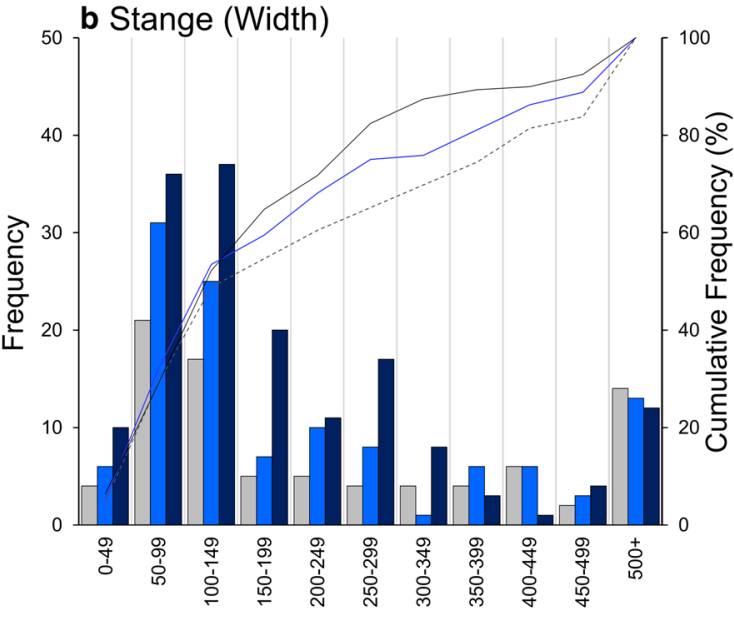

Fracture Width $(\mathrm{m})$

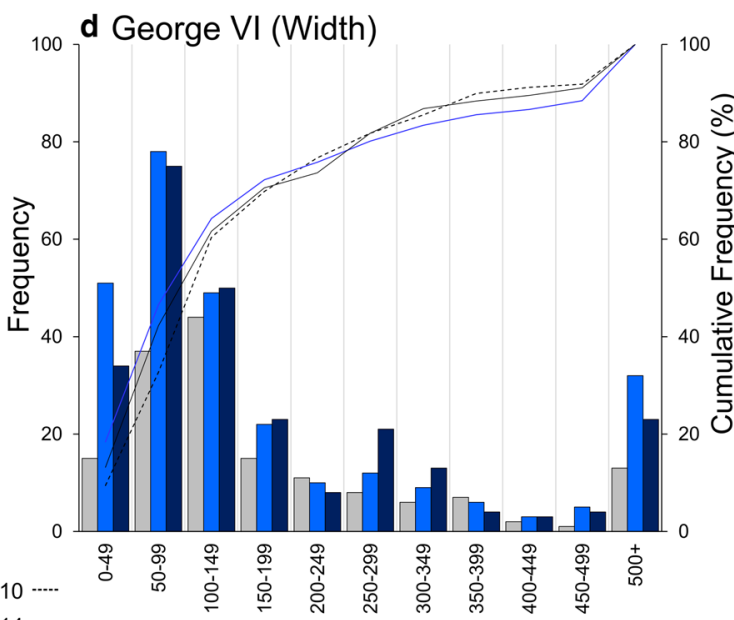

Fracture Width $(\mathrm{m})$

Fig. 6. Open fracture lengths and widths for Stange ( $a$ and b) and George VI (c and d). Note different scales on primary $y$-axis. Bach Ice Shelf not represented here owing to low numbers of open fractures identified. The lines represent the cumulative frequency of fracture lengths and widths and help illustrate the size distribution and change in size distribution through time. See Table 4 for further statistics. See Figures 7 and 8 for spatial analysis.

either (1) changes are driven by a long-term decline in inland icesheet dynamics in western Palmer Land, or (2) this portion of the ice shelf, which flows through a confined channel between Rydberg Peninsula and Case Island, has thinned sufficiently to enhanced lateral drag (Holt and others, 2014), as also observed on Larsen B Ice Shelf as it thinned (Vieli and others, 2007).

\section{George VI Ice Shelf (North)}

Our analysis of flow speeds at George VI North suggests acceleration at Riley Glacier's grounding zone of up to $120 \mathrm{~m} \mathrm{a}^{-1}$, and $\sim 50 \mathrm{~m} \mathrm{a}^{-1}$ towards the ice front, compared to ca. 2008. These earlier flow speeds of Rignot and others (2011) were taken prior to a large calving event that removed ice from the central and western portion of the calving front, and exposed an area of heavily fractured shelf ice that originated from Alexander Island (Figs 10a-d).

At its western margin, two polynyas were observed in each of the measurement periods (Figs 10b-d), the largest of which is associated with the greatest areal loss between 2009/10 and 2019/20. The smaller polynya, $\sim 3 \mathrm{~km}$ further east, emerges from a sub-surface (basal) channel of which the surface expression is visible in satellite imagery. Warmer CDW is known to flow beneath the ice shelf's cavity (Potter and others, 1984; Potter and Paren, 1985; Holland and others, 2010), and polynyas have been observed along the western margin of George VI Ice Shelf in satellite imagery since the 1970s (Holt and others, 2013). We suggest similar processes are taking place here as discussed for Stange Central; warmer water is guided beneath the ice shelf through sub-surface channels and emerges at the ice front where it melts sea ice and thins the ice front. We also associate localised fracture initiation to this process; alongside the smaller polynya are two open fractures that developed between 2014 and 2015 (Fig. 10c). These fractures ultimately became the calving boundary for two tabular icebergs that detached in 2019/20 (Fig. 10d), aided by the presence of the polynyas and removal of sea ice that adjoined the ice front.

There is a small fracture in the centre of the ice front $(\sim 600 \mathrm{~m}$ long, $15-30 \mathrm{~m}$ wide) that was first observed in 2019/20 (inset in Fig. 10d). There is a clear association with this fracture and a large, extensive crack in the sea ice, illustrating the importance of sea-ice dynamics on the stability of a calving front, and particularly that of George VI North. Finally, in 2019/20, a polynya was also observed at the eastern margin of George VI North near Riley Glacier (Fig. 10d), with open water inside open fractures that our analysis illustrated lengthened and widened throughout the observation period.

The combination of all the above events may have led to an increase in flow from Riley Glacier and at George VI North's ice front. This may lead to further fracturing and enhanced 


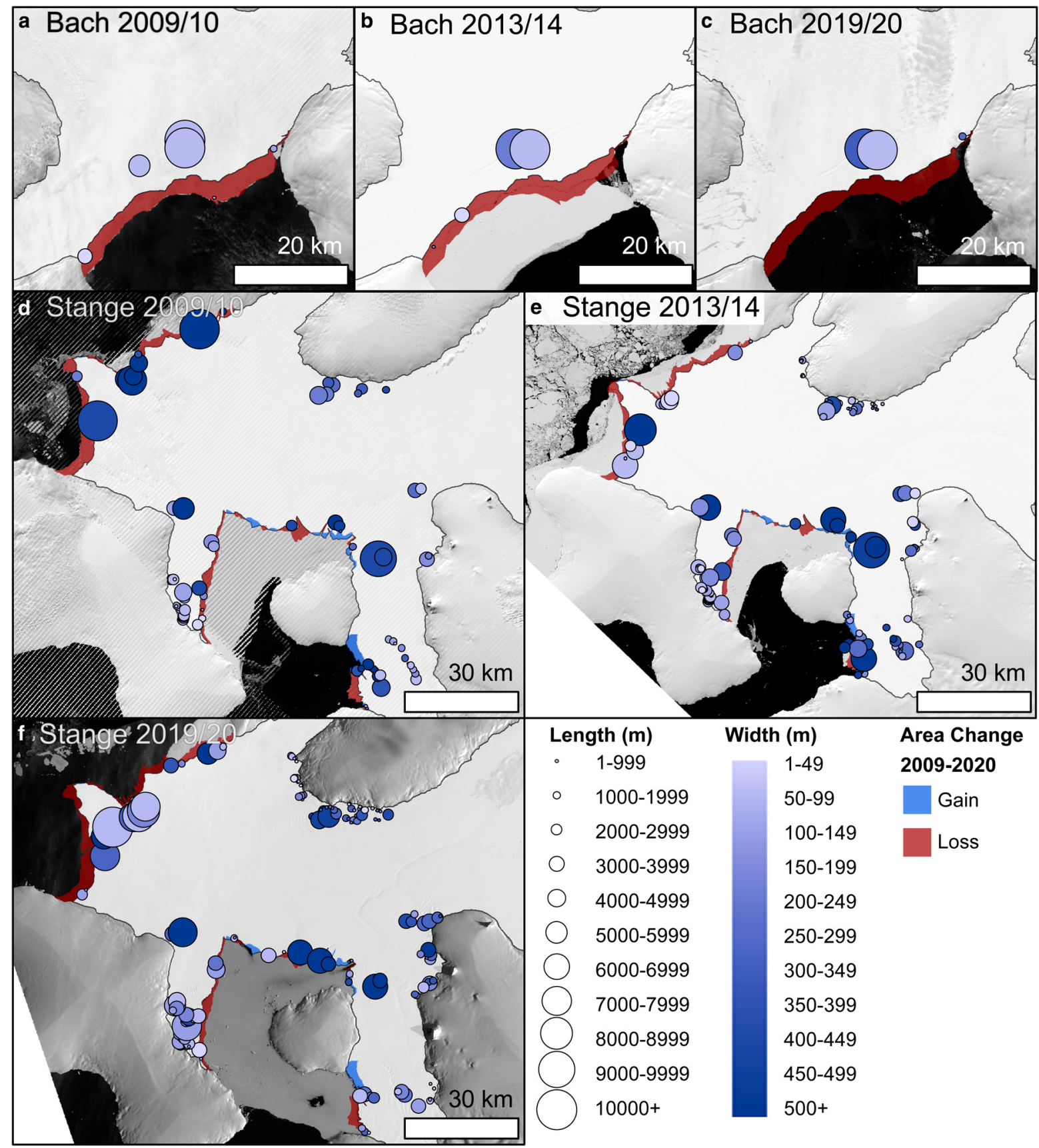

Fig. 7. Spatial distribution of open fractures for 2009/10, 2013/14 and 2019/20 for Bach (a-c) and Stange (d-f). Fracture lengths and widths categorised using histogram bins (see Fig. 6). Fracture length is represented by circle size and fracture width is represented by colour ramp, with darker blue illustrating wider fractures. Circle location represents the fracture's centre point. Area change (gains and losses) also shown.

calving either in regions where polynyas are present, or as sea ice breaks up.

\section{George VI Ice Shelf (South)}

At George VI South, fractures - both open and smooth - dominate the ice shelf. In most cases they initiate near a grounding line or ice rumple and migrate downstream towards the two main calving fronts; some transient fractures develop at the ice front and lead to discrete calving events. Our analysis shows open fractures became more frequent, wider and longer between 2009/10 and 2019/20 despite some being removed by calving events (a total net loss of $497.2 \mathrm{~km}^{2}$, was recorded, concentrated around the Eklund Islands).

Between the Eklund Islands and DeAtley Island, particularly in its eastern portion where the ice is thinner (Fig. 1c), the shelf is scattered with large, wide and often chaotic fractures, some of which contain a melange of tabular and toppled icebergs, sea ice and open water (Figs 10e-h). Since the recession of the ice front between 1973 and 2010 (Holt and others, 2013) - and from then until 2020 - this region has become increasingly unstable. More fractures (open and smooth) that developed due to enhanced flow - observed here and previously in Holt and others (2013) and Hogg and others (2017) - are approaching the ice front at an accelerated rate. These have the potential to enhance the rate of calving along this southern ice front.

Between Monteverdi Peninsula and the Eklund Islands, the removal of heavily fractured shelf ice between 2009/10 and 2013/14 exposed the area to the north the Eklund Islands and enabled 'smooth' fractures (e.g. filled surface fractures or the surface expression of basal fractures that have not been quantitatively analysed here) to widen (Figs $10 \mathrm{i}-\mathrm{j}$ ). In 2009, there were 


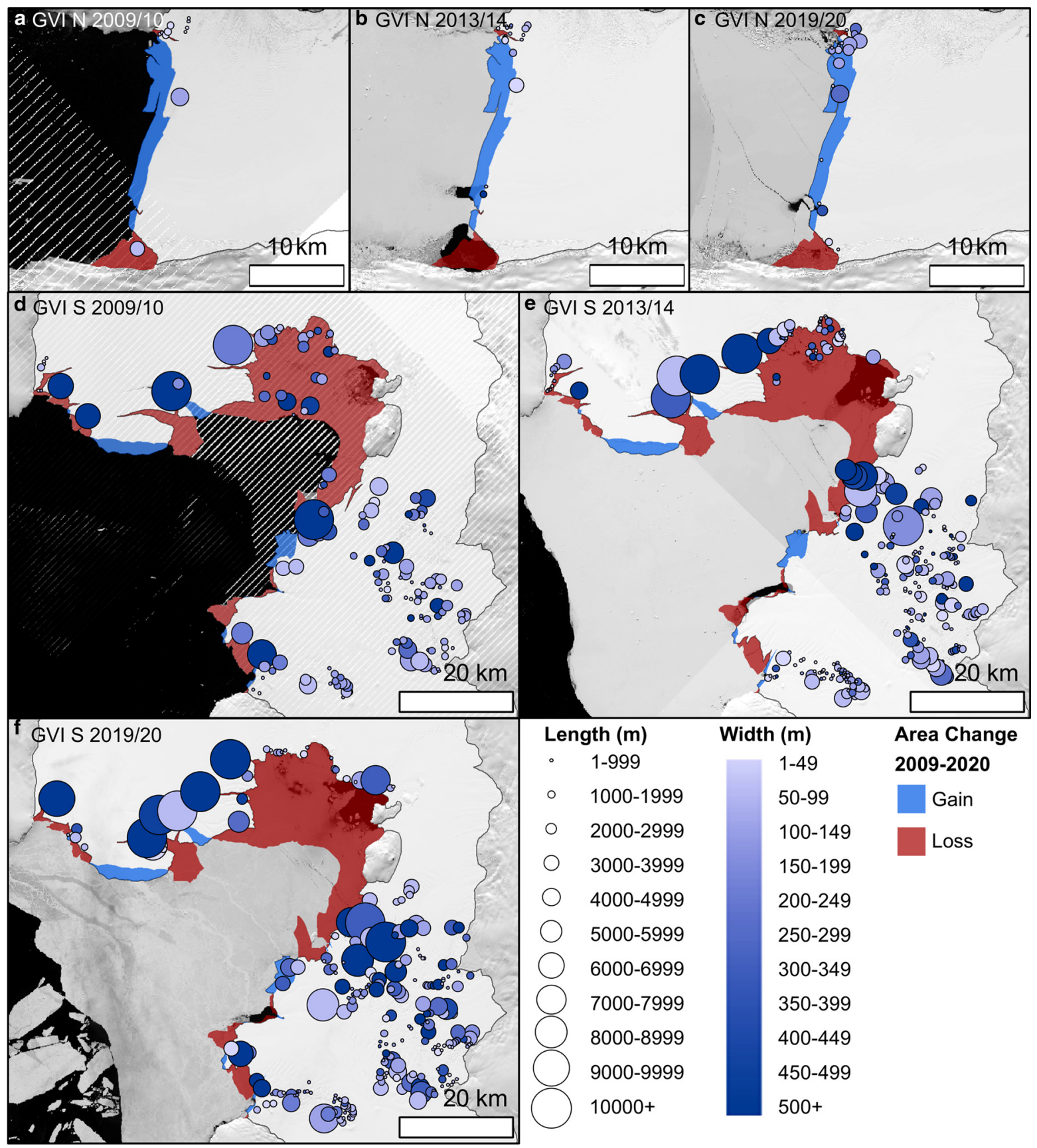

Fig. 8. Spatial distribution of open fractures for 2009/10, 2013/14 and 2019/20 for George VI North (a-c) and George VI South (d-f). Fracture lengths and widths categorised using histogram bins (see Fig. 6). Fracture length is represented by circle size and fracture width is represented by colour ramp, with darker colours illustrating wider fractures. Circle location represents the fracture's centre point. Area change (gains and losses) also shown.

only two large open fractures in this zone, emanating from the northern-most ice rumple; by 2019/20, there were five (Figs $10 \mathrm{~d}-\mathrm{f}$ ) cutting deeper into the ice shelf than at any point previously observed in the satellite era. These will unquestionably become the boundaries for large tabular icebergs as they move towards the true ice-front position, which itself is primed for calving following the propagation of a large rift since ca. 1996 (Holt and others, 2013). We do not observe any notable increase in flow speed between ca. 2008 and 2019/20 in this portion of the southern ice front, suggesting that the ice that was present around the Eklund Islands ice rumples in 2009/10 did not provide any significant buttress to flow. Indeed, it was thin (Fig. 1c), heavily fractured (Fig. 10i) and slow flowing (Fig. 1b), and unlikely to provide any great resistance to the thicker flow unit driven by GT02 and Envisat Ice Stream about 100-150 $\mathrm{km}$ upstream.

\section{Long-term stability of southwest Antarctic Peninsula ice shelves}

Adusumilli and others (2018) reported widespread thinning of Bach, George VI and Stange ice shelves from 1994 to 2016, with particularly high elevation-change rates (approaching $-0.2 \mathrm{~m} \mathrm{a}^{-1}$ ) along the English Coast grounding line of George VI South and Stange South, with lower rates $\left(<0.2 \mathrm{~m} \mathrm{a}^{-1}\right)$ for George VI North, Stange North and Central, and all of Bach. Between 2011 and 2016, slight increases in the surface elevation of Stange North and Bach were attributed to surface accumulation and changes in firn variability (Adusumilli and others, 2018). While we do not measure it here, it is probably that the exceptional surface melt observed in the austral summer of 2019/20 (Banwell and others, 2021; Barnes and others, 2021) removed part of the ice-shelf surface and led to further firn compaction. 
Table 4. Open fracture statistics for Bach, Stange and George VI ice shelves

\begin{tabular}{|c|c|c|c|c|c|c|c|c|c|c|c|c|}
\hline & \multicolumn{3}{|c|}{ Bach } & \multicolumn{3}{|c|}{ Stange } & \multicolumn{3}{|c|}{ George VI North } & \multicolumn{3}{|c|}{ George VI South } \\
\hline & $2009 / 10$ & $2013 / 14$ & $2019 / 20$ & $2009 / 10$ & $2013 / 14$ & $2019 / 20$ & $2009 / 10$ & $2013 / 14$ & $2019 / 20$ & $2009 / 10$ & $2013 / 14$ & $2019 / 20$ \\
\hline Number measured & 6 & 4 & 3 & 86 & 116 & 159 & 11 & 18 & 19 & 148 & 259 & 239 \\
\hline Length max. (m) & 18444 & 22820 & 23419 & 11330 & 8355 & 13204 & 4895 & 3931 & 4013 & 20998 & 15088 & 17348 \\
\hline Length min. (m) & 1042 & 447 & 2498 & 585 & 301 & 303 & 389 & 201 & 470 & 388 & 139 & 174 \\
\hline Length mean $(\mathrm{m})$ & 7153 & 11306 & 15603 & 2320 & 2336 & 2218 & 1431 & 922 & 1645 & 2326 & 1818 & 2379 \\
\hline Length std dev. (m) & 7286 & 11085 & 11391 & 2031 & 1649 & 2375 & 1315 & 851 & 1086 & 2469 & 2228 & 2664 \\
\hline Width max. (m) & 138 & 217 & 346 & 4523 & 2155 & 3164 & 112 & 1309 & 359 & 6601 & 1843 & 2832 \\
\hline Width min. (m) & 41 & 24 & 62 & 20 & 25 & 40 & 20 & 14 & 11 & 34 & 17 & 19 \\
\hline Width mean (m) & 78 & 115 & 225 & 374 & 280 & 446 & 52 & 148 & 114 & 276 & 198 & 226 \\
\hline Width std dev. (m) & 34 & 90 & 147 & 686 & 370 & 668 & 29 & 297 & 95 & 647 & 260 & 334 \\
\hline
\end{tabular}

The long-term trends in surface lowering are typically attributed to the presence of $\mathrm{CDW}$ encountering the thickest portions of George VI Ice Shelf (draft $>300 \mathrm{~m}$ ), and seasonal shifts in oceanic processes impacting on Stange and Bach ice shelves that occupy shallower water (Padman and others, 2012).

A combination of ice-shelf thinning and ice-front recession is observed alongside increases in ice-shelf flow speeds and grounded ice discharge along western Palmer Land (Hogg and others, 2017), apart from those discussed above for Stange South. In the southern region of south George VI Ice Shelf, between the Eklund Islands and DeAtley Island, the long-term removal of buttressing shelf ice is likely to have an impact on the dynamics of tributary glaciers, causing extensional, dynamic thinning and subsequent drawdown of inland ice, as observed elsewhere in Antarctica (e.g. Rignot and others, 2008; Joughin and others, 2014). Conversely, we do not record an increase in flow speed at the ice front located between Monteverdi Peninsula and DeAtley Island on George VI South, despite an increase in discharge at the grounding zone of $\sim 30 \%$ (from 10.3 to $13.4 \mathrm{~km}^{3} \mathrm{a}^{-1}$ between 1995 and 2016: Hogg and others, 2017). Here, enhanced discharge is attributable to ice-shelf thinning in the deepest part of the ice shelf, rather than any changes at the ice front which is about $150 \mathrm{~km}$ further west, and perhaps too far away for ice-front processes to transmit to, and beyond, the grounding zone.

We next consider the impact of likely future calving on the stability of the three ice shelves studied here. Using stress-field assimilation into an ice flow model, Fürst and others (2016) calculated the area of 'passive ice' on ice shelves around Antarctica: i.e. the portion of ice shelf that can be removed without major implications for its dynamics. Their calculations (using data from ca. 2008) showed that for Bach, Stange and George VI ice shelves, the percentage of passive ice remaining was low (3.2, 8.8 and $4.3 \%$ respectively; Table 1 ), thus further recession could yield important dynamic consequences as Schannwell and others (2016) and Schannwell and others (2018) model. Figure 11 illustrates the position of the passive ice buttressing threshold calculated by Fürst and others (2016), the 2008-2009 ice shelf extents, and the present ice-front configuration. It also shows major fractures, and a qualitative examination of areas most likely to be 'at risk' owing to the current structural and dynamic conditions.

Between 2009/10 and 2019/20, Bach's ice front started to recede beyond the ca. 2008 buttressing threshold (Fig. 11a). Given the position and length of the two large fracture sets, imminent calving (worst-case scenario) would remove all but a small fraction of passive ice at its eastern pinning point, permitting a change in ice-front stress regime and ice-shelf dynamics. Between 2009/10 and 2019/20, the ice front receded at an average rate of $350 \mathrm{~m} \mathrm{a}^{-1}$, and the two large fractures advected towards the ice front at an average rate of $120 \mathrm{~m} \mathrm{a}^{-1}$. If this continues, and the fractures remain in their present form, the western tip of the southern-most fracture will reach the receding ice front by 2025/26 where large-scale calving of the convex area is highly likely. We consider this to be the best-case scenario for changes at the ice front of Bach Ice Shelf.

The narrative for Stange Ice Shelf is much more complex owing to the atypical ice flow and structural regimes at each of the ice fronts. For Stange North, the areas most at risk are those bounded by lengthening and widening fractures. These include a $68 \mathrm{~km}^{2}$ portion west of the prominent ice front and a $15 \mathrm{~km}^{2}$ region at its eastern pinning point (Fig. 11b). Removal of ice from here would result in the front receding beyond Fürst and others' (2016) buttressing threshold. The future of the remaining section of the northern ice front remains debatable (marked '?' in Fig. 11b). Given the nature of the longitudinal fractures in the centre of the ice front, the prominent area could 'peel' away in a north-westerly direction (Fig. 11b), leaving the rest of the ice front primed for enhanced calving along pre-existing weaknesses. These processes are likely to operate on decadal timescales, and there is no imminent threat of widescale ice-front recession at Stange North.

At Stange Central and Stange South (Figs 11b-c), the ice front is already close to the buttressing threshold, with areas at risk coinciding with the ca. 2008 regions of passive ice. However, given the comparatively slow recession of Stange Central, and its atypical flow regime, immediate calving is unlikely, even if polynyas become a persistent feature in Carroll Inlet. At Stange South, we have shown that ice in its western portion cycles through periods of advance and iceberg calving along pre-existing fractures, with its average, long-term ice-front position remaining largely stable. Therefore, we also suggest that it is unlikely that the ice front will recede beyond the buttressing threshold at Stange South.

We consider the two fronts at George VI separately, given their independent nature. At George VI South, between Monteverdi Peninsula and the Eklund Islands (Fig. 11d), the buttressing threshold is up to $20 \mathrm{~km}$ from the present ice front, though our analysis illustrates that this region is now more heavily fractured than at any other point in the satellite era. The area most at risk is bounded by the largest rift at the ice front that has been developing since the mid-1990s; calving of a $15 \mathrm{~km}^{2}$ portion is imminent (years). Beyond that, we expect the fracture emanating near the Monteverdi Peninsula margin to continue to propagate into the shelf (average rate $\sim 3.5 \mathrm{~km} \mathrm{a}^{-1}$ ), and merge with one of the four pre-existing fractures propagating at rates between 3.2 and $8 \mathrm{~km} \mathrm{a}^{-1}$ (see Fig. 11e and figure caption). Calving along any of these fractures would remove up to $270 \mathrm{~km}^{2}$ of ice from George VI South ('d(i)' in Fig. 11d), and while such a calving event may have an impact on local ice-shelf dynamics (area d(ii)) is still unlikely to recede beyond the buttressing threshold to cause any major changes to the wider ice-shelf dynamics. 


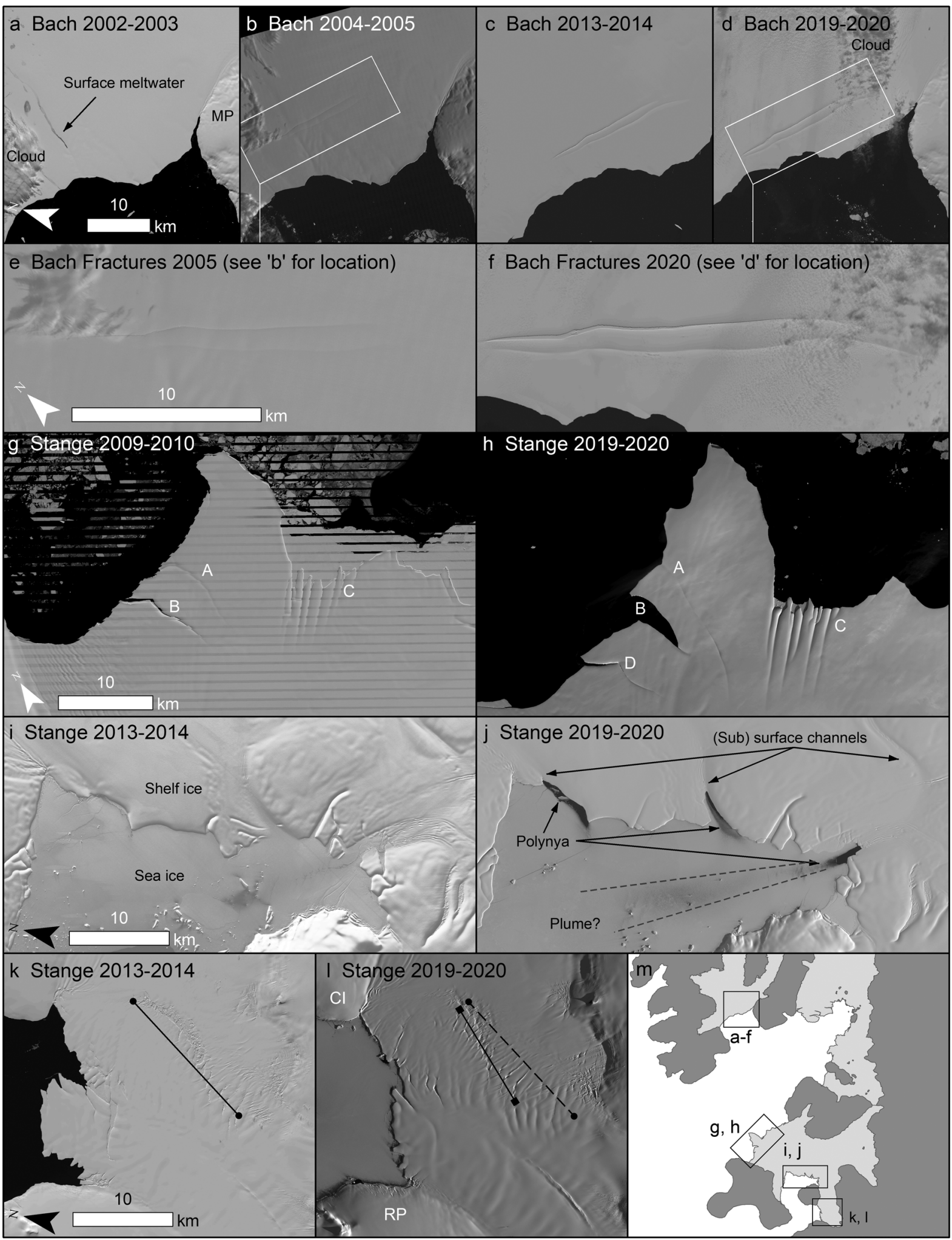

Fig. 9. Features of interest for Bach (a-f) and Stange ( $g-l)$ ice shelves as discussed in the sections 'Bach Ice Shelf' and section 'Stange Ice Shelf', respectively. Figures (a-f) illustrate the development and propagation of two large fractures on Bach Ice Shelf. MP = Monteverdi Peninsula. Panels ( $g$ ) and ( $h$ ) show fracture development in the centre of Stange North around the prominent area that juts out into Ronne Entrance. Panels (i) and (j) compare extensive and less extensive (thinner) sea ice in Carroll Inlet adjacent to Stange Central. Note the polynyas and possible plume that exit (sub) surface channels - which are thought to represent the surface expression of basal channels in the ice shelf. Panels $(k)$ and $(l)$ illustrate the closing of shear fractures and migration towards the centre of the Stange South. The solid lines in $(\mathrm{k})$ and $(\mathrm{l})$ represent approximate length of shear zone in 2013-14 and 2019-20. The dashed line in (l) represents the shear fracture distribution shown in (k) for comparative purposes only. RP, Rydberg Peninsula.

The area surrounding the Eklund Islands is unlikely to change significantly because the southern end of the ice shelf is pinned against the ice rises and ice rumples that sit below the ice shelf (Fig. 11d). Flow around and over these obstacles causes localised fracturing, but also slows flow and stabilises the ice shelf. The only area that displays calving potential here is marked ' $\mathrm{d}(\mathrm{iii})$ ' in Figure $11 \mathrm{~d}$, where a $4 \mathrm{~km}$-long concave ice front continues to calve. 


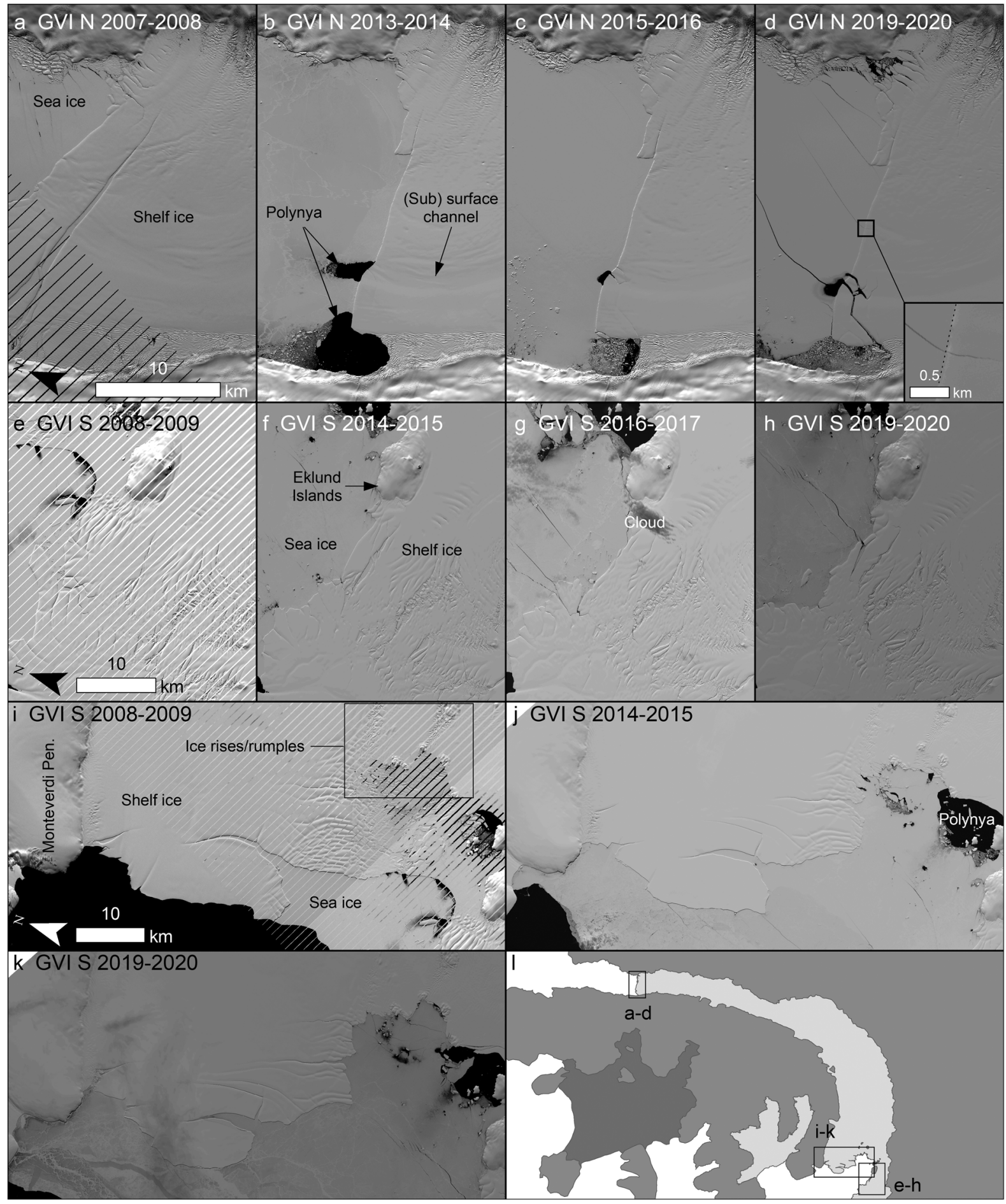

Fig. 10. Features of interest for George VI Ice Shelf. Panel (a) shows the extent of George VI North prior to a large calving event in 2008. Panels (b-d) show the development of polynyas in the sea ice adjacent to the ice front and recession of the ice front at Alexander Island. Insert in (d) illustrates a small fracture that formed in the ice shelf as the sea ice began to break up. Also note the tabular icebergs that have calved from the front in (d), associated with the two polynyas. Panels (e-h) show the development of fractures (open and smooth) west of the Eklund Islands. Panels (i-k) illustrate ice-front recession and increased number of open fractures between Monteverdi Peninsula and the Eklund Islands. Panel (I) is the location of panels (a-k).

At George VI South, between the Eklund Islands and DeAtley Island (Fig. 11f), the ice front extends beyond the buttressing threshold for much of its length. The area most at risk has already receded beyond Fürst and others' (2016) buttressing threshold, and the imminent removal of an existing partly-detached block will prime this region for further recession along increasingly wide fractures as they approach the receding ice front. Further east towards DeAtley Island, the ice shelf has fewer fractures and is, therefore, more structurally stable. We do not expect any significant change to overall ice-front position here, but with accelerating flow of thinning ice (Adusumilli and others, 2018), we would expect this area to become more susceptible to fracturing prior to enhanced calving (over decadal timescales).

At George VI North, calving between 2007/08 and 2009/10 removed the remaining area that Fürst and others (2016) calculated to be passive ice; the current ice front sits between 8 and $3 \mathrm{~km}$ behind the buttressing threshold (Fig. 11g). At the Palmer Land and Alexander Island pinning points, further recession is expected in heavily crevassed ice that is also impacted by the emergence of warm meltwater from the ice-shelf cavity. We 


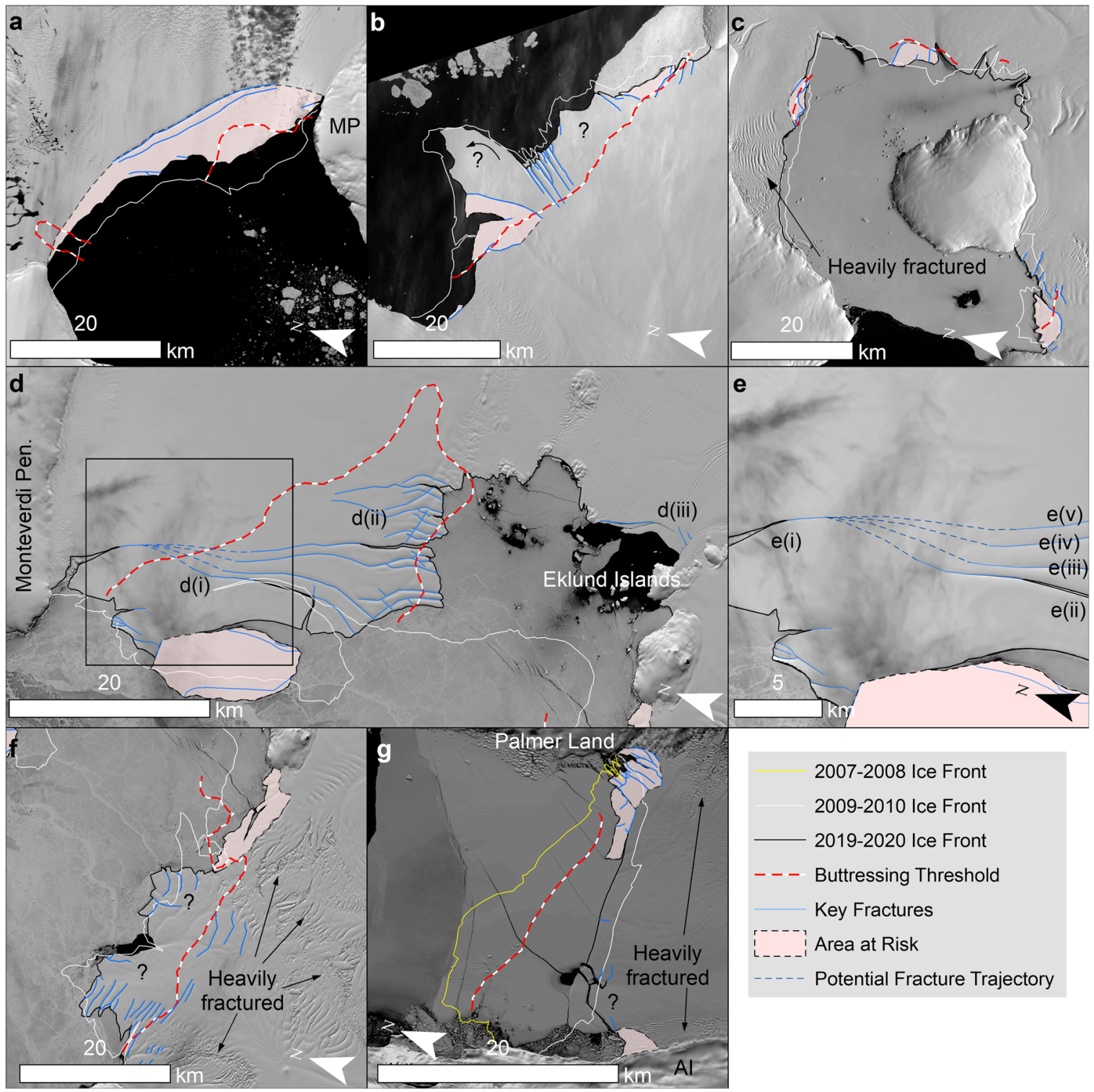

Fig. 11. Analysis of ice-front stability depicting areas most 'at risk', along with ice-front positions (2009/10 and 2019/20), key fractures and fracture zones, and the passive ice buttressing threshold taken from Fürst and others (2016). (a) Bach Ice Shelf and the position of the two large fractures that are nearing a receding ice front (MP, Monteverdi Peninsula). (b) Stange North. Of note here are the extensive longitudinal fractures that cut back into the ice shelf either side of the prominent area in the centre of the ice front. Areas denoted '?' discussed in the text. (c) Stange Central and Stange South. (d) George VI South between Monteverdi Peninsula and the Eklund Islands. Areas denoted 'd(i), d(ii) and d(iii)' discussed in section 'George VI Ice Shelf (South)'. (e) Potential fracture trajectories that could cause the area denoted d(i) to calve. Propagation rates: e(i) $3.5 \mathrm{~km} \mathrm{a}^{-1}$, e(ii) $3.2 \mathrm{~km} \mathrm{a}^{-1}$, e(iii) $4.1 \mathrm{~km} \mathrm{a}^{-1}$, e(iv) $8 \mathrm{~km} \mathrm{a}^{-1}$ and e(v) $7.5 \mathrm{~km} \mathrm{a}$. (f) George VI South between the Eklund Islands and DeAtley Island. Adjacent to the largest Eklund Island the ice shelf has already calved beyond the buttressing threshold calculated by Fürst and others (2016). Elsewhere, the ice front protrudes beyond the threshold and is comparatively stable (marked '?'). (g) George VI North where the ice front receded beyond the buttressing threshold following the 2008 calving event, which we link to a speed up of ice flow and increasing number and dimensions of open fractures. Al, Alexander Island.

have already noted the enhanced flow speeds associated with Riley Glacier, and combined with continued ice-shelf thinning from its surface and base, this region could see further fracture development (decades). This supports Holt and others' (2013) analysis that it is ultimately the dynamic configuration of Riley Glacier that will determine the long-term stability of this portion of George VI Ice Shelf, and monitoring of its flow speed and structural development is recommended over the coming years.

\section{Summary and conclusions}

We analysed a suite of freely available, fine-resolution (10-15 m per pixel) satellite imagery to quantify the glaciological changes to Bach, Stange and George VI ice shelves on the Southwest Antarctic Peninsula. We measured ice-shelf area changes from
$2009 / 10$ to $2019 / 20$, calculated flow speeds for $2019 / 20$, and undertook structural analysis for 2009/10, 2013/14 and 2019/20, focusing on open fracture characteristics. Our key findings are:

- All three ice shelves have continued to lose mass, although the spatial and temporal patterns of mass gain and loss vary for each ice shelf and for each ice front. In total, a net loss of $797.5 \mathrm{~km}^{2}$ was recorded.

- The front of Bach Ice Shelf became increasingly concave. Our analysis indicates an increase in flow speed in its main flow units and reveals the development and propagation of two large fractures migrating towards a receding ice front. We suggest that the remaining convex portion of the ice front will likely disappear by $2025 / 26$, removing the compressive arch and 
remaining portion of passive shelf ice. The ice front will then be primed for further, enhanced recession.

- Stange North recorded a net areal loss of $156.1 \mathrm{~km}^{2}$. Fractures at its calving front became longer and wider, and notably at both sides of the prominent area in the centre of the ice front. Further iceberg calving could destabilise this portion, leading to a change in stress regime elsewhere along the northern front.

- At Stange Central, polynyas were noted for the first time in Carroll Inlet that promoted increased iceberg calving between 2015 and 2017. Meltwater plumes were also detected in thinner sea ice in Carroll Inlet. Further calving is expected along well-developed fractures associated with the subsurface meltwater channels, though significant change to the ice front's stability is not expected.

- At Stange South, flow speeds continued to decrease; we suggest continued ice-shelf thinning has enhanced lateral drag in this confined channel. Open fractures began to close as longitudinal compressive stresses increased. Here, the ice-front position has remained largely stable over the satellite record, undergoing cycles of advance and recession. We do not expect any significant changes here.

- George VI Ice Shelf's southern ice-front recession allowed fractures to widen and lengthen, with enhanced calving anticipated over the coming years-to-decades. It is unlikely that all 'passive ice' will be removed, and a combination of convex ice-front geometries and presence of stabilising pinning points will limit short-term ice-front recession. However, we documented continued acceleration of the ice shelf between the Eklund Islands and DeAtley Island, and as the ice continues to thin we expect further fracture development, which may promote enhanced calving over longer time scales (decades).

- According to Fürst and others' (2016) calculations and our observations, there is no more passive ice located at George VI North. We note an increase in flow speed along Riley Glacier, combined with a widening and lengthening of fractures. We also observe the influence of subsurface meltwater on the formation of polynyas, and subsequently where iceberg calving is focused. There is a strong connection between sea-ice breakup and removal, and enhanced iceberg calving into Marguerite Bay.

Supplementary material. The supplementary material for this article can be found at https://doi.org/10.1017/jog.2022.7.

Data. Primary data generated through this research can be requested by emailing the corresponding author in the first instance.

Acknowledgements. We thank three anonymous reviewers and the Journal's editors for their constructive and timely comments that helped improve the final manuscript.

Author contributions. T.H. and N.F.G. designed the study. T.H. carried out data processing and data analysis, and wrote the majority of the manuscript with input from N.F.G.

\section{References}

Adusumilli S and 5 others (2018) Variable basal melt rates of Antarctic Peninsula ice shelves, 1994-2016. Geophysical Research Letters 45(9), 4086-4095. doi: 10.1002/2017GL076652

Banwell AF and 7 others (2021) The 32-year record-high surface melt in 2019/2020 on the northern George VI Ice Shelf, Antarctic Peninsula. The Cryosphere 15(2), 909-925. doi: 10.5194/tc-15-909-2021

Banwell AF, MacAyeal DR and Sergienko OV (2013) Breakup of the Larsen B Ice Shelf triggered by chain reaction drainage of supraglacial lakes. Geophysical Research Letters 40(22), 5872-5876. doi: 10.1002/2013GL057694

Banwell AF, Willis IC, Macdonald GJ, Goodsell B and MacAyeal DR (2019) Direct measurements of ice-shelf flexure caused by surface meltwater ponding and drainage. Nature Communications 10(1), 730. doi: 10.1038/ s41467-019-08522-5
Barnes TJ and 5 others (2021) Changes in supraglacial lakes on George VI Ice Shelf, Antarctic Peninsula: 1973-2020. The Cryosphere Discussion 2021, 119. doi: $10.5194 /$ tc-2021-214

Barrand NE and 6 others (2013) Trends in Antarctic Peninsula surface melting conditions from observations and regional climate modeling. Journal of Geophysical Research: Earth Surface 118(1), 315-330. doi: 10.1029/ 2012JF002559

Berthier E, Scambos TA and Shuman CA (2012) Mass loss of Larsen B tributary glaciers (Antarctic Peninsula) unabated since 2002. Geophysical Research Letters 39(13), L13501. doi: 10.1029/2012GL051755.

Bindschadler R, Vaughan DG and Vornberger P (2011) Variability of basal melt beneath the Pine Island Glacier ice shelf, West Antarctica. Journal of Glaciology 57(204), 581-595. doi: 10.3189/002214311797409802

Braun M, Humbert A and Moll A (2009) Changes of Wilkins Ice Shelf over the past 15 years and inferences on its stability. The Cryosphere 3(1), 41-56. doi: $10.5194 /$ tc-3-41-2009

Bromirski PD, Sergienko OV and MacAyeal DR (2010) Transoceanic infragravity waves impacting Antarctic ice shelves. Geophysical Research Letters 37(2), L02502. doi: 10.1029/2009GL041488.

Congedo L (2016) Semi-Automatic Classification Plugin Documentation. Release 6.0.1.1.

Cook AJ and 5 others (2016) Ocean forcing of glacier retreat in the western Antarctic Peninsula. Science (New York, N.Y.) 353(6296), 283-286. doi: $10.1126 /$ science.aae 0017

Cook AJ and Vaughan DG (2010) Overview of areal changes of the ice shelves on the Antarctic Peninsula over the past 50 years. The Cryosphere 4(1), 7798. doi: 10.5194/tc-4-77-2010

Cooper APR (1997) Historical observations of Prince Gustav Ice Shelf. Polar Record 33(187), 285-294. doi: 10.1017/S0032247400025389

Doake CSM, Corr HFJ, Rott H, Skvarca P and Young NW (1998) Breakup and conditions for stability of the northern Larsen Ice Shelf, Antarctica. Nature 391(6669), 778-780. doi: 10.1038/35832

Fieber KD and 5 others (2018) Rigorous 3D change determination in Antarctic Peninsula glaciers from stereo WorldView-2 and archival aerial imagery. Remote Sensing of Environment 205, 18-31. doi: 10.1016/j.rse.2017.10.042

Fretwell P and 59 others (2013) Bedmap2: improved ice bed, surface and thickness datasets for Antarctica. The Cryosphere 7(1), 375-393. doi: 10. 5194/tc-7-375-2013

Fricker HA and Padman L (2012) Thirty years of elevation change on Antarctic Peninsula ice shelves from multimission satellite radar altimetry. Journal of Geophysical Research: Oceans 117(C2), C02026.

Friedl P, Seehaus TC, Wendt A, Braun MH and Höppner K (2018) Recent dynamic changes on Fleming Glacier after the disintegration of Wordie Ice Shelf, Antarctic Peninsula. The Cryosphere 12(4), 1347-1365. doi: 10.5194/ tc-12-1347-2018

Fürst JJ and 6 others (2016) The safety band of Antarctic ice shelves. Nature Climate Change 6(5), 479-482. doi: 10.1038/nclimate2912

Fyke JG, Carter L, Mackintosh A, Weaver AJ and Meissner KJ (2010) Surface melting over ice shelves and ice sheets as assessed from modeled surface air temperatures. Journal of Climate 23(7), 1929-1936. doi: 10. 1175/2009jcli3122.1

Glasser NF and 7 others (2009) Surface structure and stability of the Larsen C ice shelf, Antarctic Peninsula. Journal of Glaciology 55(191), 400-410. doi: $10.3189 / 002214309788816597$

Glasser NF and 5 others (2011) From ice-shelf tributary to tidewater glacier: continued rapid recession, acceleration and thinning of Röhss Glacier following the 1995 collapse of the Prince Gustav Ice Shelf, Antarctic Peninsula. Journal of Glaciology 57(203), 397-406. doi: 10.3189/ 002214311796905578

Glasser NF and Scambos TA (2008) A structural glaciological analysis of the 2002 Larsen B ice-shelf collapse. Journal of Glaciology 54(184), 3-16. doi: $10.3189 / 002214308784409017$

Heid T and Kääb A (2012) Evaluation of existing image matching methods for deriving glacier surface displacements globally from optical satellite imagery. Remote Sensing of Environment 118, 339-355. doi: 10.1016/j.rse. 2011.11.024

Hogg AE and 11 others (2017) Increased ice flow in Western Palmer Land linked to ocean melting. Geophysical Research Letters 44(9), 4159-4167. doi: 10.1002/2016GL072110

Hogg AE and Gudmundsson GH (2017) Impacts of the Larsen-C Ice Shelf calving event. Nature Climate Change 7(8), 540-542. doi: 10.1038/ nclimate3359 
Holland PR, Jenkins A and Holland DM (2010) Ice and ocean processes in the Bellingshausen Sea, Antarctica. Journal of Geophysical Research: Oceans 115(C5), C05020. doi: 10.1029/2008JC005219.

Holt TO (2012) An Assessment on the Stability of Southwest Antarctic Peninsula Ice Shelves. PhD Aberystwyth University.

Holt TO and 7 others (2014) The structural and dynamic responses of Stange Ice Shelf to recent environmental change. Antarctic Science 26(6), 646-660. doi: 10.1017/S095410201400039X

Holt TO, Glasser NF, Quincey DJ and Siegfried MR (2013) Speedup and fracturing of George VI Ice Shelf, Antarctic Peninsula. The Cryosphere 7 (3), 797-816. doi: 10.5194/tc-7-797-2013

Hughes T (1983) On the disintegration of ice shelves: the role of fracture. Journal of Glaciology 29(101), 98-117. doi: 10.3189/S0022143000005177

Hulbe CL, Scambos TA, Youngberg T and Lamb AK (2008) Patterns of glacier response to disintegration of the Larsen B ice shelf, Antarctic Peninsula. Global and Planetary Change 63(1), 1-8. doi: 10.1016/j.gloplacha.2008.04. 001

Joughin I, Smith BE and Medley B (2014) Marine ice sheet collapse potentially under way for the Thwaites Glacier Basin, West Antarctica. Science (New York, N.Y.) 344(6185), 735-738. doi: 10.1126/science.1249055

Kulessa B, Jansen D, Luckman AJ, King EC and Sammonds PR (2014) Marine ice regulates the future stability of a large Antarctic ice shelf. Nature Communications 5(1), 3707. doi: 10.1038/ncomms4707

Le Brocq AM, Payne AJ and Vieli A (2010) An improved Antarctic dataset for high resolution numerical ice sheet models (ALBMAP v1). Earth System Science Data 2(2), 247-260. doi: 10.5194/essd-2-247-2010

Leprince S, Barbot S, Ayoub F and Avouac J (2007) Automatic and precise orthorectification, coregistration, and subpixel correlation of satellite images, application to ground deformation measurements. IEEE Transactions on Geoscience and Remote Sensing 45(6), 1529-1558. doi: 10.1109/TGRS.2006.888937

MacAyeal DR, Scambos TA, Hulbe CL and Fahnestock MA (2003) Catastrophic ice-shelf break-up by an ice-shelf-fragment-capsize mechanism. Journal of Glaciology 49(164), 22-36. doi: 10.3189/ 172756503781830863

Mankoff KD, Jacobs SS, Tulaczyk SM and Stammerjohn SE (2012) The role of Pine Island Glacier ice shelf basal channels in deep-water upwelling, polynyas and ocean circulation in Pine Island Bay, Antarctica. Annals of Glaciology 53(60), 123-128. doi: 10.3189/2012AoG60A062

Martinson DG (2012) Antarctic circumpolar current's role in the Antarctic ice system: an overview. Palaeogeography, Palaeoclimatology, Palaeoecology 335-336, 71-74. doi: 10.1016/j.palaeo.2011.04.007

Massom RA and 5 others (2018) Antarctic ice shelf disintegration triggered by sea ice loss and ocean swell. Nature 558(7710), 383-389. doi: 10.1038/ s41586-018-0212-1

Mercer JH (1978) West Antarctic ice sheet and CO2 greenhouse effect: a threat of disaster. Nature 271(5643), 321-325. doi: 10.1038/271321a0

Meredith MP and 9 others (2017) Changing distributions of sea ice melt and meteoric water west of the Antarctic Peninsula. Deep Sea Research Part II: Topical Studies in Oceanography 139, 40-57. doi: 10.1016/j.dsr2.2016.04. 019

Meredith MP and King JC (2005) Rapid climate change in the ocean west of the Antarctic Peninsula during the second half of the 20th century. Geophysical Research Letters 32(19), L19604. doi: 10.1029/2005GL024042.

Morris EM and Vaughan DG (2003) Spatial and temporal variation of surface temperature on the Antarctic Peninsula and the limit of viability of ice shelves. In Domack E, Levente A, Burnet A, Bindschadler R, Convey P and Kirby M (eds), Antarctic Peninsula Climate Variability: Historical and Paleoenvironmental Perspectives. American Geophysical Union, pp. 61-68.

National Snow and Ice Data Centre (2020) Sea Ice Index. (03/02/2021).

Padman L and 11 others (2012) Oceanic controls on the mass balance of Wilkins Ice Shelf, Antarctica. Journal of Geophysical Research: Oceans 117(C1), C01010. doi: 10.1029/2011JC007301.

Paolo FS, Fricker HA and Padman L (2015) Volume loss from Antarctic ice shelves is accelerating. Science (New York, N.Y.) 348(6232), 327-331. doi: 10.1126/science.aaa0940

Picard G, Fily M and Gallee H (2007) Surface melting derived from microwave radiometers: a climatic indicator in Antarctica. Annals of Glaciology 46, 29-34. doi: 10.3189/172756407782871684

Potter JR and Paren JG (1985) Interaction between ice shelf and ocean in George VI Sound, Antarctica. In Jacobs S (ed.), Oceanology of the Antarctic Continental Shelf. Washington, DC: AGU (Antarctic Research Series), pp. 35-58.
Potter JR, Paren JG and Loynes J (1984) Glaciological and oceanographic calculations of the mass balance and oxygen isotope ratio of a melting ice shelf. Journal of Glaciology 30(105), 161-170. doi: 10.3189/S002214300000589X

Pritchard HD and 5 others (2012) Antarctic ice-sheet loss driven by basal melting of ice shelves. Nature 484(7395), 502-505. doi: 10.1038/nature10968

Rack W, Doake CSM, Rott H, Siegel A and Skvarca P (2000) Interferometric analysis of the deformation pattern of the northern Larsen Ice Shelf, Antarctic Peninsula, compared to field measurements and numerical modeling. Annals of Glaciology 31, 205-210. doi: 10.3189/172756400781819851

Rack W and Rott H (2004) Pattern of retreat and disintegration of the Larsen B ice shelf, Antarctic Peninsula. Annals of Glaciology 39, 505-510. doi: 10. 3189/172756404781814005

Rankl M, Fürst JJ, Humbert A and Braun MH (2017) Dynamic changes on the Wilkins Ice Shelf during the 2006-2009 retreat derived from satellite observations. The Cryosphere 11(3), 1199-1211. doi: 10.5194/tc-11-1199-2017

Reeh N, Thomsen HH, Higgins AK and Weidick A (2001) Sea ice and the stability of north and northeast Greenland floating glaciers. Annals of Glaciology 33, 474-480. doi: 10.3189/172756401781818554

Reynolds JM and Hambrey MJ (1988) The structural glaciology of George VI Ice Shelf, Antarctic Peninsula. British Antarctic Survey Bulletin 79, 79-95.

Rignot E and 6 others (2008) Recent Antarctic ice mass loss from radar interferometry and regional climate modelling. Nature Geoscience 1(2), 106-110. doi: $10.1038 /$ ngeo102

Rignot E and 5 others (2019) Four decades of Antarctic ice sheet mass balance from 1979-2017. Proceedings of the National Academy of Sciences 116(4), 1095-1103. doi: 10.1073/pnas.1812883116

Rignot E, Jacobs S, Mouginot J and Scheuchl B (2013) Ice-shelf melting around Antarctica. Science (New York, N.Y.) 341(6143), 266-270. doi: 10. 1126/science. 1235798

Rignot E, Mouginot J and Scheuchl B (2011) Ice flow of the Antarctic ice sheet. Science (New York, N.Y.) 333(6048), 1427-1430. doi: 10.1126/science. 1208336

Robel AA (2017) Thinning sea ice weakens buttressing force of iceberg mélange and promotes calving. Nature Communications 8(1), 14596. doi: 10.1038/ncomms14596

Robertson R, Visbeck M, Gordon AL and Fahrbach E (2002) Long-term temperature trends in the deep waters of the Weddell Sea. Deep Sea Research Part II: Topical Studies in Oceanography 49(21), 4791-4806. doi: 10.1016/S0967-0645(02)00159-5

Rott $\mathbf{H}$ and 8 others (2018) Changing pattern of ice flow and mass balance for glaciers discharging into the Larsen A and B embayments, Antarctic Peninsula, 2011 to 2016. The Cryosphere 12(4), 1273-1291. doi: 10.5194/ tc-12-1273-2018

Rott H, Rack W and Nagler T (2007) Increased export of grounded ice after the collapse of northern Larsen ice shelf, Antarctic Peninsula, observed by Envisat ASAR. 2007 IEEE International Geoscience and Remote Sensing Symposium, pp. 1174-1176.

Rott H, Rack W, Skvarca P and Angelis HD (2002) Northern Larsen Ice Shelf, Antarctica: further retreat after collapse. Annals of Glaciology 34, 277-282. doi: 10.3189/172756402781817716

Rott H, Skvarca P and Nagler T (1996) Rapid collapse of northern Larsen Ice Shelf, Antarctica. Science (New York, N.Y.) 271(5250), 788-792. doi: 10. $1126 /$ science. 271.5250 .788

Scambos $\mathbf{T}$ and 7 others (2009) Ice shelf disintegration by plate bending and hydro-fracture: satellite observations and model results of the 2008 Wilkins ice shelf break-ups. Earth and Planetary Science Letters 280(1), 51-60. doi: 10.1016/j.epsl.2008.12.027

Scambos T, Hulbe C and Fahnestock M (2003) Climate-induced ice shelf disintegration in the Antarctic Peninsula. In Domack E, Levente A, Burnet A, Bindschadler R, Convey P and Kirby M (eds), Antarctic Peninsula Climate Variability: Historical and Paleoenvironmental Perspectives. American Geophysical Union, pp. 79-92.

Scambos TA, Hulbe C, Fahnestock M and Bohlander J (2000) The link between climate warming and break-up of ice shelves in the Antarctic Peninsula. Journal of Glaciology 46(154), 516-530. doi: 10.3189/172756500781833043

Schannwell C, Barrand NE and Radić V (2016) Future sea-level rise from tidewater and ice-shelf tributary glaciers of the Antarctic Peninsula. Earth and Planetary Science Letters 453, 161-170. doi: 10.1016/j.epsl.2016.07.054

Schannwell C, Cornford S, Pollard D and Barrand NE (2018) Dynamic response of Antarctic Peninsula ice sheet to potential collapse of Larsen $\mathrm{C}$ and George VI ice shelves. The Cryosphere 12(7), 2307-2326. doi: 10. 5194/tc-12-2307-2018 
Schmidtko S, Heywood KJ, Thompson AF and Aoki S (2014) Multidecada warming of Antarctic waters. Science (New York, N.Y.) 346(6214) 1227-1231. doi: 10.1126/science. 1256117

Stammerjohn SE, Martinson DG, Smith RC and Iannuzzi RA (2008) Sea ice in the western Antarctic Peninsula region: spatio-temporal variability from ecological and climate change perspectives. Deep Sea Research Part II: Topical Studies in Oceanography 55(18), 2041-2058. doi: 10.1016/j.dsr2.2008.04.026

Thomas ER, Dennis PF, Bracegirdle TJ and Franzke C (2009) Ice core evidence for significant 100-year regional warming on the Antarctic Peninsula. Geophysical Research Letters 36(20), L01706. doi: 10.1029/2009GL040104.

Thomas ER, Marshall GJ and McConnell JR (2008) A doubling in snow accumulation in the western Antarctic Peninsula since 1850. Geophysical Research Letters 35(1), L20704. doi: 10.1029/2007GL032529.
Turner J and 9 others (2016) Absence of 21st century warming on Antarctic Peninsula consistent with natural variability. Nature 535(7612), 411-415. doi: $10.1038 /$ nature 18645

van den Broeke M (2005) Strong surface melting preceded collapse of Antarctic Peninsula ice shelf. Geophysical Research Letters 32(12), L12815. doi: 10.1029/2005GL023247.

van den Broeke M, van de Berg WJ and van Meijgaard E (2008) Firn depth correction along the Antarctic grounding line. Antarctic Science 20(5), 513517. doi: $10.1017 /$ S095410200800148X

Vieli A, Payne AJ, Shepherd A and Du Z (2007) Causes of pre-collapse changes of the Larsen B ice shelf: numerical modelling and assimilation of satellite observations. Earth and Planetary Science Letters 259(3), 297306. doi: 10.1016/j.epsl.2007.04.050 